\title{
"Success in Opposite Direction:" Strategic Culture and the French Experience in Indochina, the Suez, and Algeria, 1945-1962
}

A Monograph

By

MAJ Coley D. Tyler

United States Army

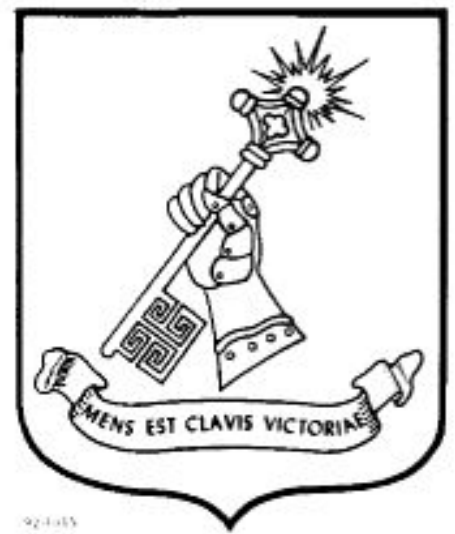

School of Advanced Military Studies

United States Army Command and General Staff College

Fort Leavenworth, Kansas

AY 2015-01 


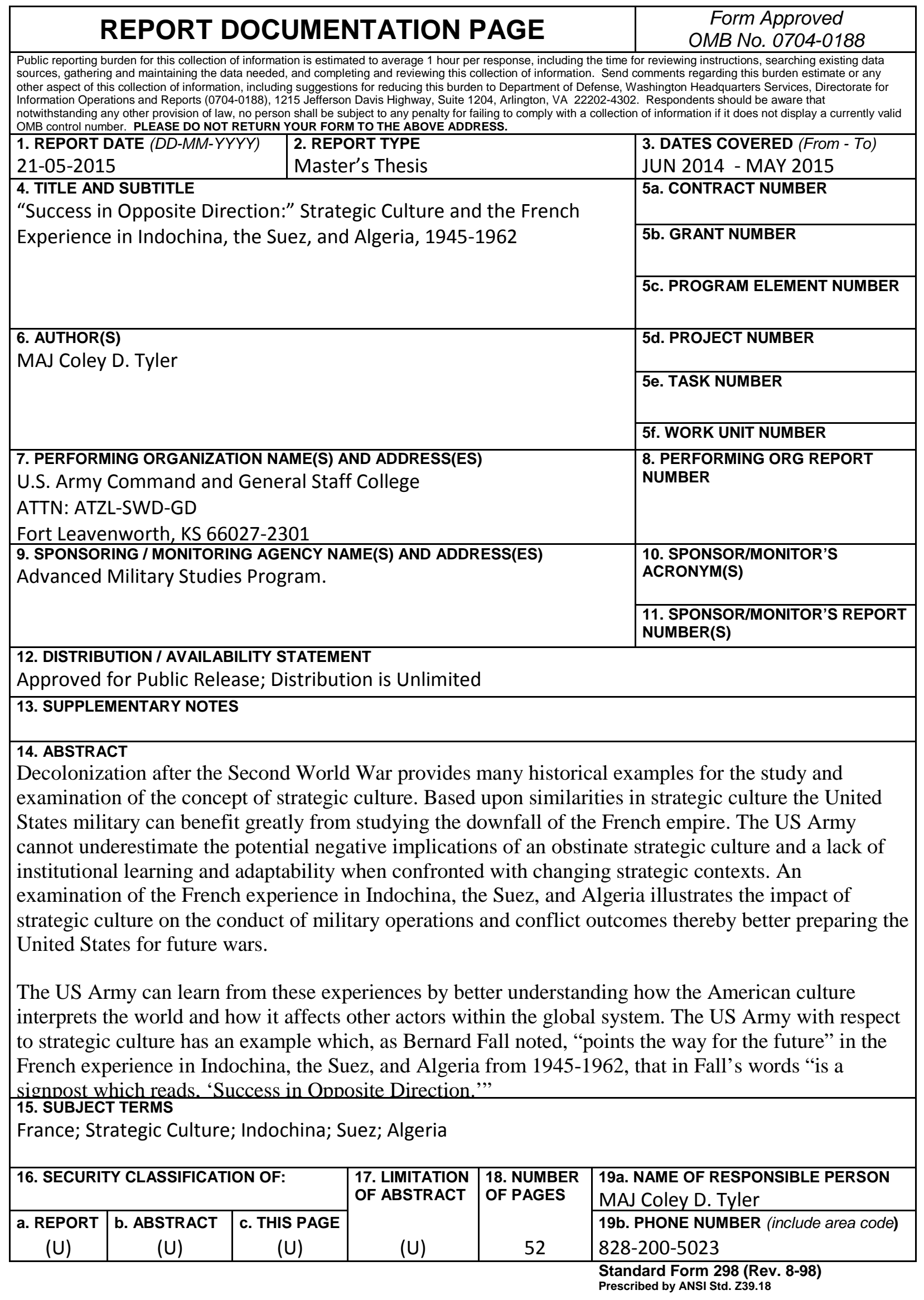




\section{Monograph Approval Page}

Name of Candidate: MAJ Coley D. Tyler

Monograph Title: "Success in Opposite Direction:” Strategic Culture and the French Experience in Indochina, the Suez, and Algeria, 1945-1962

Approved by:

Michael D. Mihalka, Ph.D.

, Monograph Director

Robert J. Hallett, LtCol, USMC

, Seminar Leader

Henry A. Arnold III, COL, IN

, Director, School of Advanced Military Studies

Accepted this $21^{\text {st }}$ day of May 2015 by:

Robert F. Baumann, Ph.D.

, Director, Graduate Degree Programs

The opinions and conclusions expressed herein are those of the student author, and do not necessarily represent the views of the U.S. Army Command and General Staff College or any other government agency. (References to this study should include the foregoing statement.) 


\begin{abstract}
"Success in Opposite Direction:" Strategic Culture and the French Experience in Indochina, the Suez, and Algeria, 1945-1962, by MAJ Coley D. Tyler, 52 pages.

Decolonization after the Second World War provides many historical examples for the study and examination of the concept of strategic culture. Based upon similarities in strategic culture the United States military can benefit greatly from studying the downfall of the French empire. The US Army cannot underestimate the potential negative implications of an obstinate strategic culture and a lack of institutional learning and adaptability when confronted with changing strategic contexts. An examination of the French experience in Indochina, the Suez, and Algeria illustrates the impact of strategic culture on the conduct of military operations and conflict outcomes thereby better preparing the United States for future wars.

The US Army can learn from these experiences by better understanding how the American culture interprets the world and how it affects other actors within the global system. The US Army with respect to strategic culture has an example which, as Bernard Fall noted, "points the way for the future” in the French experience in Indochina, the Suez, and Algeria from 1945-1962, that in Fall’s words “is a signpost which reads, 'Success in Opposite Direction.””
\end{abstract}




\section{Contents}

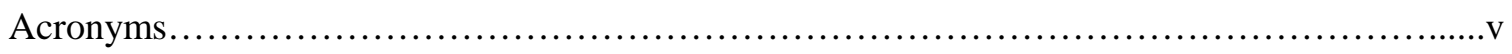

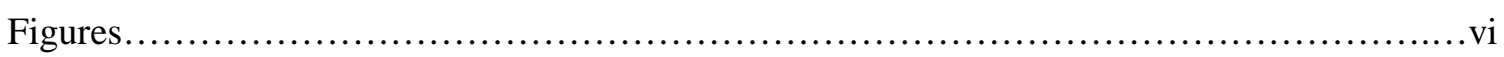

Tables..............................................................................vii

Introduction...........................................................................

Part I. Literature Review...............................................................

Strategic Culture.........................................................................

First Generation...............................................................6

Second Generation.......................................................

Third Generation.......................................................... 9

Future or Fourth Generation................................................11

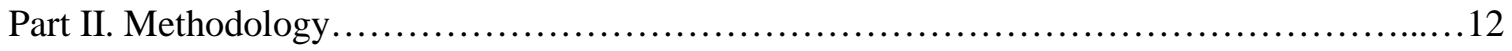

Part III. Case Studies...................................................................

French Strategic Culture.......................................................20

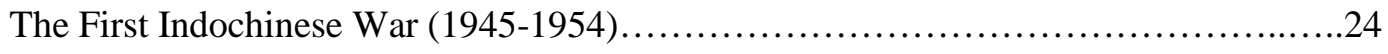

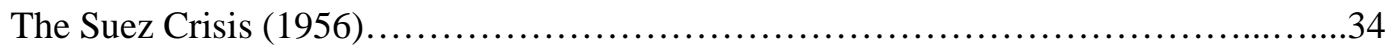

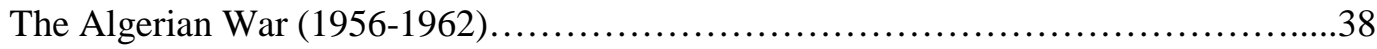

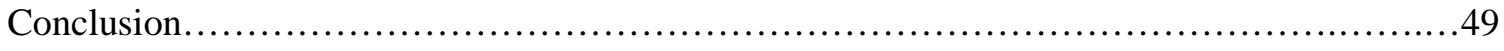

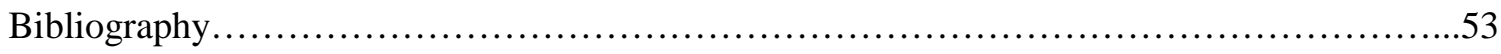




\section{Acronyms}

BEP Foreign Parachute Battalion (Battalion étranger de parachutists)

CARL Combined Arms Research Library

CGSC U.S. Army Command and General Staff College

CV Condition Variable

DRV Democratic Republic of Vietnam

DV Dependent Variable

FLN National Liberation Front (Front de Libération Nationale)

GCMA Mixed Airborne Commando Group (Groupement de Commandos Mixtes Aéroportés)

IV Independent Variable

IntV Intervening Variable

MRP Popular Republican Movement (Mouvement Républicain Populaire)

POW Prisoner of War

RC4 Colonial Route 4 (Route Coloniale 4)

REP Foreign Parachute Regiment (Régiment étranger de parachutists)

SAMS School of Advanced Military Studies

US $\quad$ United States 


\section{Figures}

Hypothesis Arrow Diagram...............................................12 


\section{Tables}

2.1 Evaluation criteria for strategic culture variable................................17

2.2 Evaluation criteria for military organizational culture variable......................17

3.1 Assessment of strategic culture variable (Indochina)...............................33

3.2 Assessment of military organizational culture variable (Indochina) ....................33

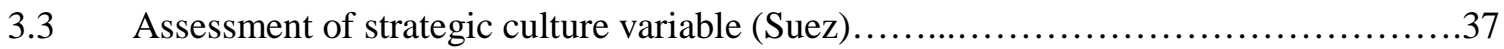

3.4 Assessment of military organizational culture variable (Suez) $\ldots \ldots \ldots \ldots \ldots \ldots \ldots \ldots \ldots \ldots$

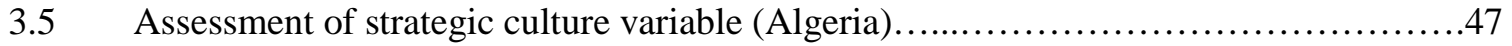

3.6 Assessment of military organizational culture variable (Algeria) $\quad \ldots \ldots \ldots \ldots \ldots \ldots \ldots \ldots . \ldots 48$

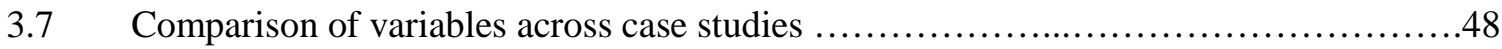




\section{Introduction}

Thus it is said that one who knows the enemy and knows himself will not be endangered in a hundred engagements. One who does not know the enemy but knows himself will sometimes be victorious, sometimes meet with defeat. One who knows neither the enemy nor himself will invariably be defeated in every engagement. ${ }^{1}$

-Sun Tzu, The Art of War

A military's interpretation of its national strategic culture within the strategic and military context of a situation plays a pivotal role in the development of operational approaches. Despite a persistent, unchanging, and influential strategic culture, the French military was able to learn from their experiences in Indochina and the Suez and develop new doctrine to guide a different operational approach in the Algerian War. Decolonization after the Second World War provides many historical examples for the study and examination of the concept of strategic culture. Based upon similarities in strategic culture the United States (US) military can benefit greatly from studying the downfall of the French empire. The French experiences in Indochina, the Suez, and Algeria are good cases in point to analyze and investigate according to Yitzhak Klein because, "[i]f strategic culture is partly a product of military experience, combat is its greatest educator. A nation with frequent combat experience is likely to fair better in choosing a strategy to fit its doctrine, and operations to execute its strategy, than one whose officers must learn from journals.”2 The connections between culture, security policy, and military action are not, however, a new concept.

Thucydides, Sun Tzu, and Clausewitz highlighted cultural influences on the military in

${ }^{1}$ Sun Tzu, The Art of War, trans. Ralph D. Sawyer (New York, NY: Basic Books, 1994), 179.

2 Jeffrey S. Lantis, "Strategic Culture and National Security Policy," International Studies Review 4, no. 3 (2002): 108. 
their writings. ${ }^{3}$ Thucydides explained the behavior of the warring parties of the Peloponnesian War by the political and cultural differences between the city-states, along with the initiation and conduct of the war by the different character of individual nations and leaders. ${ }^{4}$ Sun Tzu was a proponent of knowing oneself and the enemy on a profounder level; a standard rarely met as adversaries most often wage war in cultural ignorance of one another. ${ }^{5}$ Clausewitz described war as an act of force to compel an enemy to do your will—where will is a moral quality and therefore, culture is the source. ${ }^{6}$

American political scientist Jack Snyder introduced strategic culture in 1977 while trying to explain the differences in Soviet and American nuclear strategies. ${ }^{7}$ Political scientists have heatedly debated the usefulness, role, and exact meaning of strategic culture since its debut in academic literature. Based upon this discourse, strategic culture has a role to play as a means to discern relevant trends in the diverse contexts US military forces are likely to encounter in the future. ${ }^{8} \mathrm{~A}$ failure to understand the strategic context of a particular situation and how it correlates with a given strategic culture and way of war can have drastic consequences. Operational planners must have enough self-awareness and understanding to recognize potential implications. Strategic culture informs different approaches to operational art, “ways of war,” doctrine, and

${ }^{3}$ Ibid., 93.

${ }^{4}$ Rashed Uz Zaman, "Strategic Culture: A “Cultural” Understanding of War," Comparative Strategy 28, no. 1 (2009): 70-71.

${ }^{5}$ Colin S. Gray, "Out of the Wilderness: Prime Time for Strategic Culture," Comparative Strategy 26, no. 1 (2007): 12.

${ }^{6}$ Ibid., 11; Carl von Clausewitz, On War, trans. Michael Howard and Peter Paret (Princeton: Princeton University Press, 1984), 75, 78, 184.

${ }^{7}$ Heiko Biehl, Bastian Giegerich, and Alexandra Jonas, "Introduction," in Strategic Cultures in Europe: Security and Defence Policies across the Continent, ed. Heiko; Giegerich Biehl, Bastian; Jonas, Alexandra (Potsdam, DE: Springer VS, 2013), 9.

${ }^{8}$ Darryl Howlett, The Future of Strategic Culture, Comparative Strategic Cultures Curriculum Project (McLean, VA: SAIC, 2006), 3. 
how belligerents could act in a crisis. ${ }^{9}$

The US Army cannot underestimate the potential negative implications of an obstinate strategic culture and a lack of institutional learning and adaptability when confronted with changing strategic contexts. Rashed Uz Zaman argues that culture plays an important role in explaining how other countries fight and behave in wars and, "that it is much more important for the U.S. to understand motivation, intent, method, and culture than to have 'a few additional meters of precision, knots of speed, or bits of bandwidth."”10

Elizabeth Keir postulates that strategic culture drives political decisions that military organizational culture interprets to determine doctrine. ${ }^{11}$ Theo Farrell supports Kier in that culture shapes military organizational members' decisions through professional norms and national traditions, "by telling [them] who they are, and what is possible, and thereby suggesting what they should do." ${ }^{12}$ In essence, culture explains why military organizations act the way they do. French strategic culture and military interpretations of that culture within the strategic and military contexts of Indochina, the Suez, and Algeria played a significant role in the conduct of those military operations and their outcomes.

An examination of French strategic and military organizational culture in Indochina, the Suez, and Algeria will ascertain if this relationship holds true in explaining French military choices in those conflicts and by extension if this concept is useful to the US military for operational planning. Bernard Brodie believes, “good strategy presumes good anthropology and

${ }^{9}$ Ibid.

${ }^{10} \mathrm{Uz}$ Zaman, 69.

${ }^{11}$ Elizabeth Kier, "Culture and Military Doctrine: France between the Wars," International Security 19, no. 4 (1995): 68.

12 Theo Farrell, "Culture and Military Power," Review of International Studies 24, no. 03 (1998): 416. 
sociology" and "[s]ome of the greatest military blunders of all time have resulted from juvenile evaluations in this department." ${ }^{13}$ With all that said, studying strategic culture might help a military better understand itself, adversaries, and the world; however, it is not the single panacea principle in the Jominian sense to win wars. ${ }^{14}$ Strategic culture analysis done well can increase understanding of how others perceive a certain situation thereby reducing uncertainty in decisions made, but done badly, it can reinforce stereotypes and eliminate potential alternative solutions deemed inappropriate based upon poor assumptions. ${ }^{15}$

A literature review of the strategic culture dialogue in the subsequent section provides a synopsis of the various viewpoints within the political science field of study. The literature review identifies the theory or theories of strategic culture, variables, and methodologies of interest in assessing its causal impact. A review of this literature lays the groundwork for understanding strategic culture and the inherent issues that exist within the discipline. The methodology section explains the chosen methodology to test the validity of the modeled hypothesis. Process tracing of the selected case studies will provide evidence to support or refute the stated thesis through the examination of events in Indochina, the Suez, and Algeria. ${ }^{16}$ Finally, selected case studies will address French strategic culture, its origins, history, development, and effect on the determination of operational approaches for the conflicts in Southeast Asia and Northern Africa.

${ }^{13}$ Gray, 3.

${ }^{14} \mathrm{Uz}$ Zaman, 83.

${ }^{15}$ Alastair Iain Johnston, "Thinking About Strategic Culture," International Security 19, no. 4 (1995): 63-64.

${ }^{16}$ Stephen Van Evera, Guide to Methods for Students of Political Science (Ithaca, NY: Cornell University Press, 1997), 65. 


\section{Part I}

\section{Literature Review}

Strategic culture has been a major topic among political scientists since 1977. There is no sign the debate among interested professionals will cease anytime soon. There are too many aspects of strategic culture yet to have consensus such as its exact definition, its contribution in understanding the international security environment, and the proper methodology for its use in scientific studies. David Haglund does not believe this failure to come to agreement over strategic culture's meaning or applicability is a bad thing, but just goes to show how interesting a concept it is. ${ }^{17}$ Haglund further stresses that with the concept in its embryonic stage disagreement is perfectly healthy and only helps to advance its theoretical understanding as differing ideas attempt to sharpen strategic culture as a tool for analysis. ${ }^{18}$ Currently followers of strategic culture fall into several camps most commonly referred to as generations or waves. ${ }^{19} \mathrm{Uz}$ Zaman describes the first two generations as "broad descriptive" due to the broad historical analysis of patterns of behavior in specific nation-states, attributing their behavior to culture, and forecasting those historical patterns into the future. ${ }^{20}$ Uz Zaman terms the third and fledgling fourth generation of strategic culturalists as the "analytical school" based upon the use of narrower definitions and rigorous methods for testing effects on specific classes of strategic behavior. ${ }^{21}$

${ }^{17}$ David G. Haglund, "What Good Is Strategic Culture?: A Modest Defence of an Immodest Concept," International Journal 59, no. 3 (2004): 1.

${ }^{18}$ Ibid., 2.

19 Johnston, 36, 39, 41; Elizabeth Stone, Comparative Strategic Cultures Literature Review (Part 1), Comparative Strategic Cultures Curriculum Project (McLean, VA: SAIC, 2006), 1.

${ }^{20}$ Uz Zaman, 73.

${ }^{21}$ Ibid. 


\section{First Generation}

The first generation or wave dates from the early 1980s and focuses on Snyder’s original works on strategic culture in explaining American and Soviet differences in nuclear strategy. ${ }^{22}$ Snyder defined strategic culture as, "the sum total of ideas, conditioned emotional responses, and patterns of habitual behavior that members of a national strategic community have acquired through instruction or imitation and share with each other with regard to nuclear strategy.” ${ }^{23}$ The biggest proponents of the first generation school of thought are Colin S. Gray and David Jones who consider unique variations in macro environmental variables such as deeply rooted historical experiences, political culture, and geography as the causes of strategic culture. ${ }^{24}$

The first generation's concept of strategic culture is that it helps generate understanding of strategic decision-making. ${ }^{25}$ The variables of culture condition actors, shape how they deal with situations, and provide context for understanding rather than explanatory causality of behavior. ${ }^{26}$ Strategic culture can provide reasons for action, but cannot determine them, yet helps offer insight into likely future behavior. ${ }^{27}$ The first generation believes that culture is the prime conveyor of "thought, judgment, and policy" and must always be present as an actual or potential influence on strategic behavior and decisions. ${ }^{28}$ Jones defines three levels of input to strategic culture. The highest level is the macro environmental level mentioned previously with geography,

22 Stone, 1.

${ }^{23}$ Jack L. Snyder, The Soviet Strategic Culture: Implications for Limited Nuclear Operations (Santa Monica, CA: Rand, 1977), 8.

${ }^{24}$ Johnston, 36.

${ }^{25}$ Frank Komrij, "Strategic Culture and Divergent Security Policies of European States," E-International Relations Students, last modifed June 17, 2012, accessed October 10, 2014, http://www.e-ir.info/2012/06/17/strategic-culture-and-divergent-policies-of-european-states/.

${ }^{26}$ Ibid.

${ }^{27}$ Ibid.

${ }^{28}$ Gray, 9. 
ethno cultural characteristics, and history as subcomponents. ${ }^{29}$ The intermediate level is the societal level and consists of social, economic, and political structures as the instruments of input. ${ }^{30}$ The lowest level of input is the micro level comprised of military institutions and the characteristics of civil-military relations. ${ }^{31}$

Some of the weaknesses of the first generation point of view are problems with the definition of strategic culture, the current concept's unwieldiness, the assumption that strategic culture subsumes behavior and the contention of a society’s strategic cultural consistency across time. ${ }^{32}$ More specifically, Alastair Iain Johnston points out that if strategic culture is the product of all relevant explanatory variables then there is no room for non-strategic culture explanations of strategic choice. ${ }^{33}$ Furthermore, the first generation stance on strategic culture rules out the possibility of disjuncture between strategic culture and behavior, therefore, they show no appreciation of potential conscious manipulation by decision-makers. ${ }^{34}$ Finally, as unwieldy as the first generation concept is there are concerns with how to derive an observable strategic culture by describing what sources or time periods to examine. ${ }^{35}$

\section{Second Generation}

In the mid-1980s, another wave or second generation emerged within the strategic culture community. The motivation for branching out from the first generation was the belief in the

\footnotetext{
${ }^{29}$ Johnston, 37.

${ }^{30}$ Ibid.

${ }^{31}$ Ibid.

32 Stone, 1.

33 Johnston, 37.

${ }^{34}$ Ibid., 38.

${ }^{35}$ Ibid., 39.
} 
premise that there is a big difference in what a national leader says they are doing compared to the deeper motives for what they in fact do. ${ }^{36}$ Bradley S. Klein as the primary spokesperson for the second generation of strategic culturalists argues that strategic culture is a product of historical experience; consequently, strategic culture and behavior do not share a linkage. Strategic choice therefore is a reflection of the interests of hegemonistic groups. ${ }^{37}$ Strategic culture subsequently is a tool of political hegemony in the realm of strategic decision-making. ${ }^{38}$

Second generation followers recognized a potential disconnection between symboliccultural discourse and operational doctrine when looking at world powers from a Gramscian perspective. ${ }^{39}$ In the minds of second-generation scholars, leaders use the symbolic-cultural discourse to perpetuate the hegemony of strategic elites and allow them to implement their designs and plans. ${ }^{40}$ The second generation does not take for granted the natural existence of strategic culture affecting the behavior of different security communities, but instead argues in favor of the examination of the strategic practices that serve to constitute these communities and their interrelationships. ${ }^{41}$ The second generation believes that individuals [leaders] who have responsibility for the communication and perpetuation of strategic culture must have the ability to influence it. ${ }^{42}$ Based upon this belief, Klein and others, focus on how strategic practices constitute an identity unlike Gray and Johnston who ascribe to cultural attributes affecting strategic

\footnotetext{
${ }^{36}$ Stone, 1.

${ }^{37}$ Johnston, 40.

${ }^{38}$ Stone, 1.

${ }^{39}$ Uz Zaman, 73-74.

${ }^{40}$ Ibid.

${ }^{41}$ Edward Lock, "Refining Strategic Culture: Return of the Second Generation," Review of International Studies 36, no. 3 (2010): 687.

42 Ibid., 693.
} 
practices. ${ }^{43}$ The second generation also differs from the first in that they are moving away from broad generalizations of national character and more towards a detailed analysis of communicative practices from those involved in strategic politics. ${ }^{44}$ Ultimately, researchers must investigate long-term behavior not just assume a certain pattern of existence. ${ }^{45}$ As an example, the second generation does not adhere to the belief that historically and culturally rooted notions about the end, ways, and means of war limit strategic choices. ${ }^{46}$

As with the first generation, there are weaknesses with how Klein understands strategic culture. The primary shortcomings are issues with symbolic discourse and the linkage between strategic culture and behavior. ${ }^{47}$ There is debate whether elites are able to withstand the constraints of strategic culture or if they actually become socialized within the myths that they and their predecessors were instrumental in creating. ${ }^{48}$ It is also unclear if there should be crossnational differences. ${ }^{49}$ Future research to support the second generation should focus on how strategic elites use strategic culture to mask or obscure choices made in the interest of domestic and international political hegemons. ${ }^{50}$

\section{Third Generation}

The third generation came along in the 1990s with Johnston's more rigorous

\footnotetext{
${ }^{43}$ Ibid., 698.

${ }^{44}$ Ibid., 699.

${ }^{45}$ Ibid., 701.

${ }^{46}$ Johnston, 43.

${ }^{47}$ Stone, 1.

${ }^{48} \mathrm{Uz}$ Zaman, 78.

${ }^{49}$ Stone, 1.

${ }^{50}$ Johnston, 43.
} 
conceptualization of strategic culture as an independent variable and more narrowly focused attention on specific strategic decisions as dependent variables. ${ }^{51}$ This generation's main purpose is to make strategic culture falsifiable. ${ }^{52}$ The third generation focuses on cases where structuralistmaterialists conceptions cannot explain a particular strategic decision. ${ }^{53}$ The third generation works to avoid the determinism of the first generation and leaves behavior out of the independent variable as they conceptualize strategic culture in a way to allow variance. ${ }^{54} \mathrm{~A}$ commitment to competitive theory testing is also an important component of the third generation methodology. Important to this analysis is the work of Kier's studies of French military organizational culture as an intervening variable of strategic culture to determine the causality on military decisions such as doctrine and operational approaches. ${ }^{55}$

The third generation is not immune to weakness and shows deficiencies in their over emphasis on the flaws of realism, on the use of organizational culture as a key independent or intervening variable, and the reliance on a loose definition of strategic culture which proves difficult in making it falsifiable. ${ }^{56}$ The use of military organizational culture as a key variable does share the first generation belief that cultural variables have an observable effect on behavior and tends to contradict the third generation separation between culture and behavior. Moreover, the use of a standard definition of strategic culture - that it either presents decision-makers with a limited range of choices or acts as a lens that alters the usefulness of choices-requires other

${ }^{51}$ Stone, 1.

${ }^{52}$ Lawrence Sondhaus, Strategic Culture and Ways of War (New York, NY: Routledge, 2006), 7-8.

\footnotetext{
${ }^{53}$ Stone, 1.

${ }^{54}$ Johnston, 41.

${ }^{55}$ Ibid., 42.

${ }^{56}$ Stone, 1.
} 
variables to help explain why leaders make particular decisions ${ }^{57}$ Moving forward, the third generation needs to focus on isolating strategic culture influences on behavior and distinguishing them from the effects of other variables. ${ }^{58}$

Future or Fourth Generation

In the twenty-first century as strategic culture matures as a concept, there is the potential for the birth of a fourth generation. This generation must use the consensus that culture significantly affects national security strategy and state behavior in order to develop a unified theory of strategic culture to avoid it continuing to be the "explanation of last resort." ${ }^{59}$ Some, like Jeffrey S. Lantis, believe that neorealism is not adequate for predicting major events in a dynamic international system like the present global environment. ${ }^{60}$ Neorealism is not necessarily compatible with culture as an explanation in general. This generation will have to rely heavily on lessons learned from previous decades, construct improved notions of strategic culture, and better utilize cross-discipline studies such as sociology, psychology, political science, and international relations theory to address the relevance as applied to non-state actors in the post-9/11 world. ${ }^{61}$ Increasing ranges of global actors that possess strategic culture post 9/11 are affecting relevant trends and the identification of their competing narratives can help analyze how these factors shape behavior. ${ }^{62}$

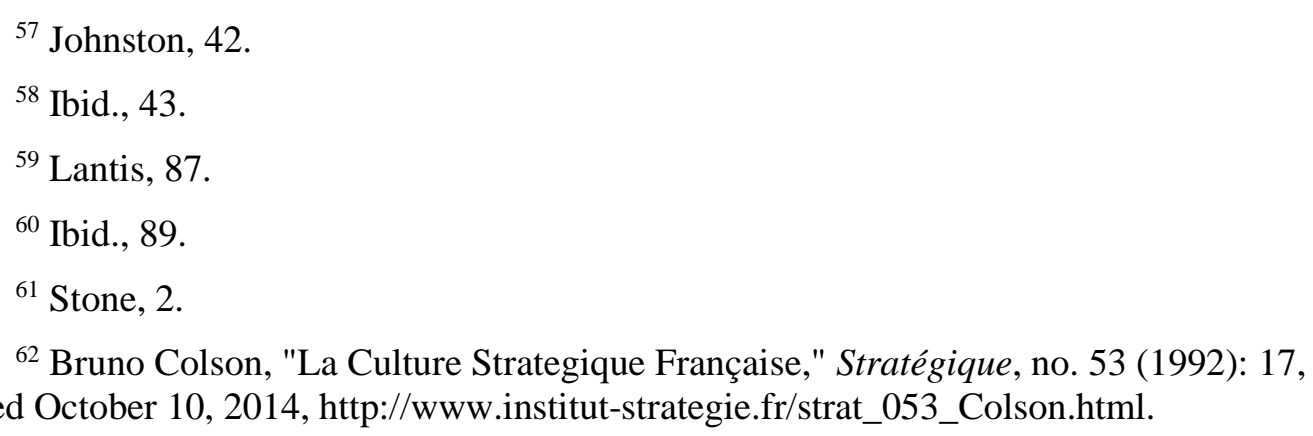


This study attempts to build upon the work of Kier and the third generation of using military organizational culture as an intervening variable between strategic culture and development of military doctrine and goes a step further by examining operational approaches to see if this concept is useful in the post-9/11 environment (fig. 1). Elizabeth Stone believes these requirements are of the utmost importance to understand non-state actors and enemies of the United States and that research must explore these if national security is to be secure. ${ }^{63}$

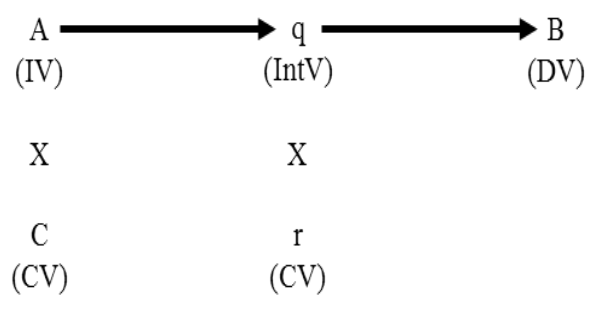

$$
\begin{aligned}
& \text { A - Strategic Culture } \\
& \text { q- Military Organizational Culture } \\
& \text { B - Operational Approach } \\
& \text { C - Strategic Context of Conflict } \\
& \text { r- Military Context of Conflict }
\end{aligned}
$$

(IV) Independent variable; (IntV) Intervening variable; (DV) Dependent variable; (CV) Condition variable framing antecedent condition

\section{Figure 1. Hypothesis Arrow Diagram.}

Source: Created by Author.

\section{Part II}

\section{Methodology}

This work utilizes the observational case study method to test the stated hypothesis that despite a persistent, unchanging, and influential strategic culture, the French military was able to learn from their experiences in Indochina and the Suez and develop new doctrine to guide a different operational approach in the Algerian War. (fig 1.) This study qualifies as qualitative research as defined by Pertti Alasuutari because of its reliance on qualitative analysis-reasoning and argumentation not solely based upon statistical relations between variables. ${ }^{64}$

${ }^{63}$ Stone, 2.

${ }^{64}$ Pertti Alasuutari, Researching Culture: Qualitative Method and Cultural Studies (Thousand Oaks, CA: Sage Publications, 1995), 7. 
Qualitative research is useful when trying to understand human behavior and the why and how of decision-making. The qualitative process of research is ideal for this study to investigate French beliefs, experiences, attitudes, behavior, and interactions as they pertain to strategic culture and the impact on military operational approaches. One of the primary categories of interest within the qualitative method, which particularly suits this topic, is document and textual analysis of written records. ${ }^{65}$

Additionally, John Stuart Mill’s “Method of Differences” has some relevance to this study. Mill postulates,

If an instance in which the phenomenon under investigation occurs, and an instance in which it does not occur, have every circumstance save one in common, that one occurring only in the former; the circumstance in which alone the two instances differ, is the effect, or cause, or a necessary part of the cause, of the phenomenon. ${ }^{66}$

The "Method of Differences" helps establish that a certain factor is sufficient to bring about a particular effect. ${ }^{67}$ Using Mill’s difference method to test this study’s hypothesis (fig 1.) should reveal that a change in the French military's organizational culture was the effect, cause, or necessity to produce a successful military approach in the Algerian War. This study prescribes to Johnston's third generation, which believes strategic culture as an independent variable can determine strategic choice. Johnston's third generation definition of strategic culture used in this study states,

Strategic culture is an integrated "system of symbols which acts to establish pervasive and long-lasting strategic preferences by formulating concepts of the role and efficacy of military force in interstate political affairs, and by clothing these conceptions with such

${ }^{65}$ Vibha Pathak, Bijayini Jena, and Sanjay Kalra, "Qualitative Research," Perspectives in Clinical Research 4, no. 3 (2013): 192.

${ }^{66}$ John Stuart Mill, A System of Logic, Ratiocinative and Inductive, Being a Connected View of the Principles of Evidence and the Methods of Scientific Investigation (London, UK: Harrison and Co., 1843), 455.

${ }^{67}$ Dave Beisecker, "Mill's Methods," University of Nevada Las Vegas, last modifed January 1, 2010, accessed January 29, 2015, https:/faculty.unlv.edu/beisecker/Courses/Phi102/Mills_Methods.htm. 
an aura of factuality that the strategic preferences seem uniquely realistic and efficacious." 68

The definition of military organizational culture used is from Elizabeth Kier's Culture and Military Doctrine: France between the Wars. Kier expresses military organizational culture "as the set of basic assumptions and values that shaped shared understandings, and the forms or practices whereby these meanings are expressed, affirmed, and communicated to the members of the organization.” ${ }^{69}$ According to the first element of Johnston's method of determining the presence of a system of symbols, France deals very much in hard realpolitik. The Central Paradigm describes a nation's tendencies by measuring the role of war (is it inevitable or an aberration), the nature of the adversarial threat (zero-sum or variable-sum), and the efficacy of the use of force (the ability to control outcomes or eliminate threats and which conditions applying forces is useful). ${ }^{70}$ The closer to believing war is inevitable, the adversarial threat posed is zerosum, and the efficacy of violence is high the closer a culture is to hard realpolitik (strategic culture).

The second element deals with assumptions on a more operational level about what options are most effective when operating in a threat environment (military organizational culture). The condition variables of strategic and military context of conflict are important influences in this determination. The strategic and military contexts of conflict regulate the impact of culture on the determined operational approaches. At the higher end of the Central Paradigm, the expectation would be to find strategies that are more offensive and on the lower end of the spectrum more accommodative or diplomatic strategies. ${ }^{71}$ Tables 2.1 and 2.2 show

\footnotetext{
68 Johnston, 46.

${ }^{69}$ Kier, 69.

${ }^{70}$ Johnston, 46-47.

${ }^{71}$ Ibid., 47.
} 
strategic culture and military organizational culture disaggregated to be of use as investigative tools to determine causality and measure influence in accordance with Johnston's first and second elements of a system of symbols. ${ }^{72}$

This examination of French strategic and military culture must address several weakness in case study analysis as well. First, case studies inherently have less of an opportunity to control for third or omitted variables compared to large- $n$ analysis and too few cases in point can provide an inadequate number of data points for consideration. ${ }^{73}$ Process tracing, though will allow the creation of a semi-controlled environment to limit third variables by utilizing examples with uniform case conditions. ${ }^{74}$ Using cases such as the First Indochinese War, the Suez Crisis, and the Algerian War, which have variable values on the extremes, limits the number of third factors and decreases the chances that omitted variables will account for a positive test. ${ }^{75}$ However, uniformity between the three conflicts could mask antecedent conditions. ${ }^{76}$ If tested predictions are unique, of which this is an instance, the ability to use the private speech and writings of primary actors helps to offset these additional weaknesses. ${ }^{77}$ Important objects of analysis are writings, debates, thoughts, and works of important military leaders, units (i.e., 1er Régiment/Battalion étranger de parachutistes), war plans, and war literature (i.e., The Centurions). ${ }^{78}$

The purpose of this study is to determine if strategic culture and military organizational

\footnotetext{
${ }^{72}$ Komrij.

${ }^{73}$ Van Evera, 51.

${ }^{74}$ Ibid., 52.

${ }^{75}$ Ibid.

${ }^{76}$ Ibid., 53.

${ }^{77}$ Ibid., 54.

${ }^{78}$ Johnston, 49.
} 
culture within the context of conflict affected the operational approaches evident in Indochina, the Suez, and Algeria. If strategic culture and military organizational culture did cause these approaches and directly affected conflict results then these lessons are good for the US military to learn. Process tracing is much easier to use in the examination of the manner in which initial case conditions translate into case outcomes. ${ }^{79}$ Process-tracing in the chosen case studies will explore the chain of events (sequence and structure) and decision-making process (testimony of participants) of key individuals and units of the French government and military and look for observable evidence to support the postulated cause and effect relationship between strategic culture, military organizational culture, and operational approach. ${ }^{80}$ Additionally, analysis of cause-effect statements through cognitive mapping and symbols analysis of idioms, phrases, key words, analogies, and metaphors will also be beneficial. ${ }^{81}$

Table 2.1 depicts the disaggregation of strategic culture and the indicators for measurement and evaluation to determine the degree to which each component factor is present. These evaluations are subjective assessments based upon the available literature and professional judgment. Table 2.2 depicts the disaggregation of the military organizational culture intervening variable and its three indicators for assessment within the chosen case studies. As with indicators of strategic culture, the evaluation of the degree of influence of the component factors is a subjective assessment based upon the literature and professional judgment.

\footnotetext{
${ }^{79}$ Van Evera, 54.

${ }^{80}$ Ibid., 64.

${ }^{81}$ Johnston, 51-52.
} 
Table 2.1 Evaluation criteria for strategic culture variable

\begin{tabular}{|l|l|}
\hline \multicolumn{1}{|l}{ Variable } & $\begin{array}{l}\text { Indicator } \\
\text { 1) Strength of national feeling } \\
\text { 2) Reaffirmation by those who are "a certain kind of France" } \\
\text { 3) Decision-making autonomy }\end{array}$ \\
\cline { 2 - 3 } $\begin{array}{l}\text { Strategic } \\
\text { Culture }\end{array}$ & $\begin{array}{l}\text { Universalism (defend and export Universal Human Rights) }{ }^{\mathrm{a}} \\
\text { 1) "Civic assimilation" (human rights, language, civic values, } \\
\text { 2) "Civilizing mission" (culture imperialism) }\end{array}$ \\
\cline { 2 - 3 } & $\begin{array}{l}\text { Great Power Status (global stature) } \\
\text { 1) Level of international ambition }\end{array}$ \\
& $\begin{array}{l}\text { 2) Foreign policy orientation } \\
\text { 3) Willingness to use military force }\end{array}$ \\
\hline
\end{tabular}

Sources: Colson, Bruno. "La Culture Strategique Française." Stratégique, 53 (1992). http://www.institut-strategie.fr/strat_053_Colson.html [accessed October 10, 2014]. ${ }^{a}$ Colson's definitions.

Sondhaus, Lawrence. Strategic Culture and Ways of War. New York, NY: Routledge, 2006.

bIdeas presented by Sondhaus.

Biehl, Heiko; Giegerich, Bastian; Jonas, Alexandra. "Introduction." Strategic Cultures in Europe: Security and Defence Policies across the Continent. Potsdam, DE: Springer VS, 2013.

${ }^{\mathrm{c}}$ Concepts presented by Biehl, Giegerich, and Jonas.

Table 2.2 Evaluation criteria for military organizational culture variable

\begin{tabular}{|c|c|}
\hline Variable & Indicator \\
\hline \multirow{3}{*}{$\begin{array}{l}\text { Military } \\
\text { Organizational } \\
\text { Culture }\end{array}$} & $\begin{array}{l}\text { Relationship to the State (positive or negative) }{ }^{\mathrm{a}} \\
\text { 1) Feeling of acceptance and value } \\
\text { 2) Centralized or decentralized control } \\
\text { 3) Level of support (monetary, logistical, manpower) }\end{array}$ \\
\hline & $\begin{array}{l}\text { Military valued skills (method and mode of combat) } \\
\text { 1) Strategy of annihilation or attrition } \\
\text { 2) Conventional or unconventional warfare } \\
\text { 3) Joint and combined operations }\end{array}$ \\
\hline & $\begin{array}{l}\text { Evaluation of the enemy (superior, peer, or inferior adversary) } \\
\text { 1) Motivation for fighting } \\
\text { 2) Ability to fight } \\
\text { 3) Capabilities for fighting }\end{array}$ \\
\hline
\end{tabular}

Source: Kier, Elizabeth. "Culture and Military Doctrine: France between the Wars." International Security 19, no. 4 (1995): 65-93.

${ }^{a}$ Ideas presented by Kier. 
Process-tracing, cognitive mapping, and symbols analysis of the conflicts in Indochina, the Suez, and Algeria based upon the variable indicators in tables 2.1 and 2.2 will provide evidence to whether or not French strategic culture persisted, changed, and influenced the military based upon the different strategic contexts of each situation. Variable indicators will also provide evidence whether or not strategic culture and military context prevented the French military from learning from their experiences and adapting their operational approach in an attempt to achieve successful conflict outcomes.

\section{Part III}

\section{Case Studies}

The experiences of France in Indochina, the Suez, and Algeria provide insight into the influence and impact of strategic culture. The French Fourth Republic (1946-1958) faced a very complicated period in French history. The conclusion of the Second World War saw France once again as a great power "even if those clothes were 'tailored too large for it." 82 The new French government encountered the issue of reasserting control over its colonial empire while trying to rebuild the reputation of the state. The French government committed their military to Indochina, the Suez, and Algeria during this period to help accomplish those goals with no success.

An examination of the French experience in Indochina, the Suez, and Algeria illustrates the impact of strategic culture on the conduct of military operations and conflict outcomes thereby better preparing the United States for future wars. Important similarities between French and American strategic culture make these case studies compelling. Much like the French after the Second World War, Americans have an overarching desire to maintain global power, which they closely relate with military might and their control over their democratic empire (Western

82 John F. V. Keiger, France and the World since 1870 (London, UK: Arnold, 2001), 62. 
states like the United States). In addition, Americans maintain a belief in the United States being the "city on the hill” and the democratic light of the world. This belief reinforces the understanding that people around the world will want to emulate the United States because of their superior culture. The French experience in Indochina, the Suez, and Algeria from 19451962, is the basis for determining if French strategic culture changed during this time period based upon the differing contexts of each of these situations. In addition, these case studies will be the sources for establishing whether the interpretation of national strategic culture by the French military influenced the operational approaches for these conflicts.

According to Keiger, "France's defense posture is affected by a national strategic culture, a set of assumptions, attitudes, and policies towards defense and security that arise from history, geography, political culture, self-perception, as well as how others perceive it." ${ }^{83}$ Long-standing and tenuous civil-military relations, however, created friction between the civilian government and the military as to the nature of the military as the implementation tool of French foreign policy. Political turmoil and frequent turnover of the government lent credence to the contentious debate over the creation of an army that was politically reliable or militarily effective. ${ }^{84}$ The French Fourth Republic was suspicious of centralized control of the military and therefore dispersed power within the government. ${ }^{85}$ Many measures of reorganization, fifteen rearrangements from 1946-1958, took place within the upper levels of the defense structure to maintain political balance between the left (liberals, socialists, and communists) and the right (conservatives, Catholics, and the military). ${ }^{86}$
${ }^{83}$ Ibid., 48.
${ }^{84}$ Ibid., 50.
${ }^{85}$ Ibid., 35.
${ }^{86}$ Ibid., 62-63; Sondhaus, 21. 
Traditional military discipline with the September 1944 commission to deal with loyal Vichy officers was "turned on its head when refusal to obey a legally constituted political authority became a virtue [Free French] and obedience [Vichy French] a crime.”87 There were 160,000 treason trials with 88,000 condemned as traitors and 7,000 traitors sentenced to death. ${ }^{88}$ The experience of the shattering defeat of 1940 and the divisiveness of choosing sides that the French military went through deeply engrained a sense of preserving their fragile unity and esprit de corps as a top priority during the decolonization period after the Second World War. ${ }^{89}$ In the midst of frequent inter-governmental confusion and quarrelling, the military was for the most part free to act as it saw fit within its understanding of the strategic and military context of the situation as civilian oversight was severely lacking. ${ }^{90}$

French Strategic Culture

Much of the strategic culture of current European states, to include France, formed during the Second World War and early Cold War years. ${ }^{91}$ The Second World War was a humiliating experience for France. They emerged from the war in a weak position and were heavily reliant on foreign aid such as the Marshall Plan. ${ }^{92}$ French exclusion from the Yalta Conference in February 1945 fostered a need to recover their image, especially with an economy and national infrastructure in shambles requiring significant time, effort, and resources to repair. ${ }^{93}$ Reality,

\footnotetext{
${ }^{87}$ Keiger, 63.
}

${ }^{88}$ George Armstrong Kelly, Lost Soldiers: The French Army and Empire in Crisis, 19471962 (Cambridge, MA: MIT Press, 1965), 4.

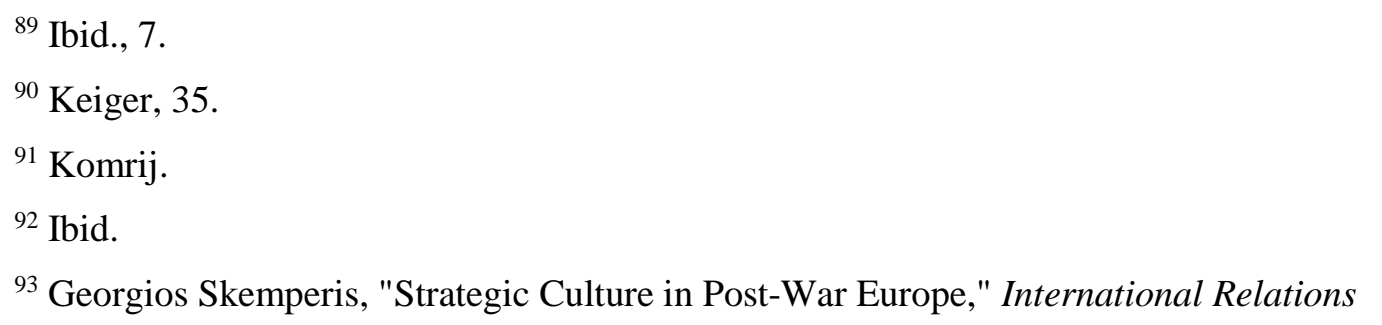


however, did not support a French core belief that they were still a great power and had a responsibility to strive to hold a prominent global position. ${ }^{94}$ At the close of the Second World War, the Allies only considered France a world power because it possessed the second largest colonial empire. ${ }^{95}$ The dominant features of French strategic culture during the Fourth Republic were the politics of empire and grandeur. ${ }^{96}$ Charles de Gaulle asserted in 1958, "France cannot be France without grandeur” when describing the global role of his country. ${ }^{97}$ At the time, "textbooks, newspapers, intellectuals, and politicians all spread the message of the empire" claiming the empire reinforced the grandeur and prestige of France..$^{98}$

The French quest to change world opinion about their global power status, though, was not essential to state survival or security and the reclamation and retention of a vast colonial empire stretched the limits of metropolitan France's resources. ${ }^{99}$ The French overestimated how much the colonies would support the rebuilding of France versus a focus on metropolitan development to reestablish their legitimacy and pursuit of recovery. ${ }^{100}$ The primary instrument of the French government to accomplish these goals was the military, but liberals and conservatives of the Fourth Republic fervently debated the nature and doctrine of the force, which caused much disorder in the military. ${ }^{101}$

The post-Second World War era was not the only instance of France trying to recover her

$$
\begin{aligned}
& \text { Program, (2003): } 18 . \\
& \quad{ }^{94} \text { Komrij. } \\
& \quad{ }^{95} \text { Skemperis, } 18 . \\
& { }^{96} \text { Ibid. } \\
& \quad{ }^{97} \text { Ibid., } 19 . \\
& \quad{ }^{98} \text { Ibid. } \\
& { }^{99} \text { Sondhaus, } 20 . \\
& { }^{100} \text { Skemperis, } 18 . \\
& { }^{101} \text { Sondhaus, } 21 .
\end{aligned}
$$


national pride or reclaim global status in the world. After the Franco-Prussian War 1870-71, the French turned to empire building to improve their reputation. ${ }^{102}$ This deterioration of the French position in the latter nineteenth and early twentieth century caused French elites to seek imperial gains. ${ }^{103}$ The French sense of geography and the belief in civic assimilation gave French colonialism a unique character. ${ }^{104}$ Paul Vidal de la Blache and his idea of "possibilism” which emphasized potential heavily influenced the French and that history was the source of geography, not the natural sciences. ${ }^{105}$ Consequently, the French considered language and biology as essential factors, but civic values and cultural identity were even more significant. ${ }^{106}$ These beliefs feed a conviction that civic assimilation into French culture within the colonies was possible. ${ }^{107}$ At the 1944 Brazzaville Conference the French declared, "[t]he aims of the civilizing mission accomplished by France in her colonies preclude the idea of autonomy or any possibility of evolution outside the French empire; the idea of a possible, even ultimate establishment of self-government in the colonies must be discarded." 108

Bruno Colson's three hallmarks of the post-1945 French strategic culture were independence, universalism, and global rank. ${ }^{109}$ These hallmarks of geopolitical culture were Vidalian, stressed the freedom and autonomy of political societies, included linguistic, economic,

102 Ibid., 22.

103 Skemperis, 18.

${ }^{104}$ Sondhaus, 21-22.

105 Ibid., 21.

106 Ibid.

107 Ibid., 22.

${ }^{108}$ Guy de Carmoy, The Foreign Policies of France, 1944-1968, trans. Elaine P. Halperin (Chicago, IL: University of Chicago Press, 1970), 128.

${ }^{109}$ Colson. 
and social ties with the colonies, and considered Paris as the political center. ${ }^{110}$ From the French perspective, colonialism was an "earth-civilizing” mission. ${ }^{111}$ In many ways, the ideals of the French Revolution still influenced the political principles of France, which conflicted with French designs for their empire. ${ }^{112}$

The colonial empire was the conduit by which to direct the French civilizing mission, bring the fruits of the Revolution to all nations, and spread Universalist values. ${ }^{113}$ In the words of John Keiger, "[t]o be true to its destiny France must spread, wherever it is able, its language, its culture, its arms, and its genius."' ${ }^{114}$ Léon Blum in 1924 bluntly summarized the French belief in a responsibility as a superior race to civilize inferior races when he stated,

We are too imbued with love of our country to disavow the expansion of French thought and civilization...We recognize the right and even the duty of superior races to draw unto them those who have not arrived at the same level of culture. ${ }^{115}$

In the French psyche their colonialism elevated and assimilated less fortunate persons into a greater society. ${ }^{116}$ Unlike other colonial powers such as Britain, the French believed their motives were altruistic and not exploitative. ${ }^{117}$ The French thought the worst choice colonies could make was to seek independence because that would be a step backward from the enlightening path provided by France. ${ }^{118}$ French leaders never comprehended that the citizens of Indochina or Algeria might feel the same way about the French as the Free French did about the Vichy and

\footnotetext{
110 Ibid.

${ }^{111}$ Ibid.

112 Skemperis, 18.

${ }^{113}$ Keiger, 200, 202.

${ }^{114}$ Ibid., 202.

115 Ibid., 204.

116 Ibid., 203.

117 Ibid.

118 Ibid.
} 
Germans in the Second World War. During the decolonization period after the Second World War, "France's defense posture [was] affected by a national strategic culture, a set of assumptions, attitudes, and policies towards defense and security that [arose] from history, geography, political culture, self-perception, as well as how others perceive[d] it."119

The First Indochinese War (1945-1954)

France began reasserting control over their colonial empire after the Second World War in Indochina. In August 1945, Charles de Gaulle sent an expeditionary force under the command of General Philippe Leclerc to reclaim Indochina in the name of France. ${ }^{120}$ De Gaulle did this despite the warnings of Vietnamese Emperor Bao Dai who begged, “[de Gaulle] to understand that the only means of safeguarding French interests and the spiritual influence of France in Indochina is recognize unreservedly the independence of Viet-Nam...”121

By October 1945, Leclerc concluded that, "[o]ne does not kill ideas with bullets" and the French needed to avoid a large-scale war with no long-term military solution that required a force beyond the capacity of France. ${ }^{122}$ Leclerc recommended to Paris that the French military reassert control over cities and lines of communications to give negotiators a base in which to pursue a political settlement. ${ }^{123}$ To this end Leclerc and Jean Sainteny, commissioner to Tonkin, signed an

${ }^{119}$ Ibid., 48.

${ }^{120}$ Carmoy, 134.

${ }^{121}$ Bao Dai, "Letter from Emporer Bao Dai to General Charles De Gaulle, August 18, 1945," in Viet-Nam Crisis: A Documentary History, ed. Allan W. Cameron (Ithaca, NY: Cornell University Press, 1971), 48-49.

${ }^{122}$ Fredrik Logevall, Embers of War: The Fall of an Empire and the Making of America's Vietnam (New York, NY: Random House, 2012), 119.

123 Ibid. 
accord with Ho Chi Minh on March 6, 1946 in Hanoi. ${ }^{124}$ This accord declared the Republic of Vietnam "as a free state...with its own government, parliament, army and finances," and promised to ratify any decisions on the union of the three states reached by popular vote. ${ }^{125} \mathrm{~A}$ month later, on April 3, General Raoul Salan of Leclerc's staff and Vietnamese Defense Minister, Vo Nguyen Giap complemented the political agreement with the Franco-Vietnamese military pact delineating the terms of military aid, training, leadership, occupation, and timeline for the withdrawal of French forces. ${ }^{126}$

Conditions were set for the successful conclusion of the French civilizing mission and civic assimilation in Indochina in which Minh stated, “[w]e look forward to having French teachers, journalists, and engineers. But no more administrators.” ${ }^{127}$ Sainteny and Leclerc put France in a position to work with Vietnamese nationalism towards common goals and created an environment in which "French technology, commerce, and civilization [were] acceptable to a movement that had all too many reasons” to turn elsewhere. ${ }^{128}$ Unfortunately, many other French officials believed these developments were detrimental to the French "policy of grandeur.”129

These differing ideas of what was best for France stemmed from the political party with the key and defining role for Indochinese policy, the Christian Democratic Mouvement

${ }^{124}$ Carmoy, 135.

${ }^{125}$ Ibid.; Jean Sainteny, Ho Chi Minh, and Vo Hong Khanh, "Franco-Vietnamese Preliminary Convention and Annex, March 6, 1946," in Viet-Nam Crisis: A Documentary History, ed. Allan W. Cameron (Ithaca, NY: Cornell University Press, 1971), 77-79.

${ }^{126}$ Philippe Devillers and Jean Lacouture, End of a War: Indochina, 1954 (New York, NY: Frederick A. Praeger, 1969), 8-9.

${ }^{127}$ R. E. M. Irving, The First Indochina War: French and American Policy, 1945-54 (London, UK: Croom Helm, 1975), 18.

${ }^{128}$ Devillers and Lacouture, 9.

129 Ibid. 
Républicain Populaire (MRP). ${ }^{130}$ French colonial policy after the Second World War was one of “progressive federalism” designed for maximum economic, social, and political progress, but without ceding French military or diplomatic prerogatives. ${ }^{131}$ The MRP preferred French colonies and territories to be a part of a greater unified French Union with France as the focal point rather than independent countries under French influence. The MRP saw Paris as being "both the spiritual home and supreme authority” much as Rome was to the Catholic Church. ${ }^{132}$ The French government could not understand why colonies imbued with French culture would want independence and not strive to be full French citizens within a greater indivisible Republic. The French government believed they "[could not] allow...the natives to rule themselves, dismember the empire, and let the people fall into the hands of the Communists. Nor [could they] expose the Catholic minorities to possible danger or deprive the West of raw materials." ${ }^{133}$ Despite being signatories to the Atlantic Charter (right of all people to choose freely their form of government) and the United Nations Charter (independence was inevitable and the only morally justifiable goal of colonization), France exercised its decision-making autonomy on the global stage, contrary to the established world order.

To this end, General Jean Valluy, Leclerc's successor, instigated clashes in Tonkin between November and December 1946 against the Vietminh. ${ }^{134}$ The events in Tonkin shattered any peaceful relationship between the French and Vietminh and open war began. The French Expeditionary Force prosecuted the First Indochinese War without a clear policy or goal due to

\footnotetext{
${ }^{130}$ Irving, 2.

${ }^{131}$ Ibid.; Kelly, 41.

132 Irving, 2.

133 Ibid., 3; Carmoy, 138.

${ }^{134}$ Kelly, 32, 42, 44.
} 
the extreme uncertainty and ambiguity that radiated from Paris. ${ }^{135}$ The war was officially never more than a colonial pacification, which precluded the use of conscripts, so the burden of the fighting fell to the traditional solution of specialized corps of professional volunteers like the French Foreign Legion. ${ }^{136}$ From the French government's perspective the military commanders in Indochina "demanded too great and too far-sighted an effort" that could have dangerous domestic political effects. ${ }^{137}$

The French military relied upon conventional methods of warfare and demonstrating their martial abilities that were lacking in the Second World War. ${ }^{138}$ Valluy and the French command believed they could enforce a political solution with military action with their armor, aircraft, paratroopers, and relative overwhelming resources. ${ }^{139}$ Early operations predicated upon parachute drops and deep armored stabs to capture Vietminh leaders encouraged French beliefs in Second World War era doctrine and the utility of units like the 1er Bataillon étranger de parachutists (1er BEP) as the key to fighting in the limiting terrain of Indochina. ${ }^{140}$

Foreign Legion commanders did not think highly of the fighting qualities of the Vietnamese and assessed they had little or no military ability even though the Legion units required specialized training for different regions and missions within Vietnam and the Vietminh did not. ${ }^{141}$ The French were not able to use Second World War doctrine effectively and struggled

135 Devillers and Lacouture, 18-19.

${ }^{136}$ Ibid., 19; Douglas Porch, The French Foreign Legion: A Complete History of the Lengendary Fighting Force, 1st ed. (New York, NY: HarperCollins Publishers, 1991), 531.

${ }^{137}$ Devillers and Lacouture, 19.

${ }^{138}$ Bernard B. Fall, Street Without Joy (Mechanicsburg, PA: Stackpole Books, 1994), 28; Porch, 517.

\footnotetext{
${ }^{139}$ Devillers and Lacouture, 17.

140 Porch, 517, 526.

${ }^{141}$ Ibid., 514-515.
} 
against the jungles of Vietnam, while the Vietminh made use of it. ${ }^{142}$ The Vietminh knowing this met French operations with withdrawals further into the hinterlands, local counterattacks, and guerrilla actions. ${ }^{143}$ Valluy consolidated his minimal gains in 1948 and focused on holding a string of outposts on the Chinese border in northeast Tonkin along Route Coloniale 4 (RC4) and the Red River Delta, while Giap and the Vietminh continued training, recruiting, and conducting guerrilla attacks on isolated French outposts. ${ }^{144}$

These outposts became increasingly important as Communist Chinese support to the Vietminh intensified. ${ }^{145}$ The 1er BEP, the first of three parachute units formed by the French Foreign Legion in 1948, quickly made a name for itself in Indochina during the battles for RC4. ${ }^{146}$ After a surprise parachute drop at Dong Khe on 27 May 1950, the 1er BEP successfully drove back the entire $308^{\text {th }}$ "Iron Brigade" of the Vietminh, one of its best units and reinforced a myth that one French parachute battalion was equal to one Vietminh brigade. ${ }^{147}$ Despite some costly tactical successes, Hungarian Legionnaire Janos Kemencei expressed a widespread belief among the paratroopers that a lack of support in equipment had much to do with the ability of units to accomplish their mission:

I think that, armed with this material, we would have doubled or tripled our efficiency...I am convinced that if we had been adequately armed (...that is, with American and other

${ }^{142}$ Fall, 11.

143 John Shy and Thomas W. Collier, "Revolutionary War," in Makers of Modern Strategy from Machiavelli to the Nuclear Age, ed. Peter Paret, Gordon A. Craig, and Felix Gilbert (Princeton, NJ: Princeton University Press, 1986), 848.

${ }^{144}$ Logevall, 207; Shy and Collier 848.

145 Porch, 520.

${ }^{146}$ French Foreign Legion, "Foreign Legion Info," last modifed January 10, 2015, accessed March 12, 2015, http://foreignlegion.info/units/1st-foreign-parachute-regiment/.

${ }^{147}$ Porch, 520. 
machine guns) we would have suffered far fewer casualties, and kept many legionnaires in a state to fight. ${ }^{148}$

The eventual loss of RC4 stirred public opinion at home, which was previously indifferent to a conflict half a world away. ${ }^{149}$ These losses made it more evident that the volunteer force might not be able to solve the Indochinese problem alone and may require draftees to deploy overseas. ${ }^{150}$ There were simply not enough elite units such as the 1er BEP to fight all the battles against the Vietminh. These consequences did not resonate well with the public and as a result, the political debate increased in Paris and politicians argued about what to do in Indochina.

Pierre Mendès-France complained of inconsistency in French policy towards Indochina and outlined two options for the French government. The French could leverage political power to give the army numbers and appropriations necessary to win or seek a political accord with the Vietminh, which he felt would be far more damaging now in 1950 than if they sought a political solution earlier. ${ }^{151}$ The financial and political realities of France at the time were incapable of supporting the beliefs of many French officials to continue the pursuit of "the defense of the free world in Indochina," and to support the soldiers "fighting over there [with] the intention and impression of also defending civilization, cultural interest, and the glory of France.”152

The only tangible outcome of these debates was the appointment of General Jean de Lattre de Tassigny on 6 December 1950 to hopefully accomplish more with what resources were already available and stem the tide of defeat. ${ }^{153}$ The events of 1950, forced the French, including

\footnotetext{
${ }^{148}$ Ibid., 528.

${ }^{149}$ Kelly, 32.

${ }^{150}$ Carmoy, 141; Kelly, 33.

${ }^{151}$ Carmoy, 141-142.

152 Kelly, 63.

${ }^{153}$ Carmoy, 142; Logevall, 255.
} 
the 1er BEP to reevaluate their Vietminh adversaries whom they had not taken very seriously to this point. ${ }^{154}$

De Lattre, considered the most successful French commander in Indochina constructed the "De Lattre Line” around the Red River Delta to keep the Vietminh out while dispatching forces throughout the interior to pacify the population. In conjunction with his defense, de Lattre, formed groupe mobiles as quick reaction forces to Vietminh attacks along the perimeter. ${ }^{155}$ While still relying on the French advantage of motorization and mechanization for defense of the critical Hanoi-Haiphong line of communication, de Lattre also realized this alone could not win the war. De Lattre made the only serious attempts at the formation of a national Vietnamese Army as an auxiliary force and of French guerrilla units (Groupement de Commandos Mixtes Aéroportés, GCMA) to better address the nature of the conflict in Indochina. ${ }^{156}$ De Lattre also furthered French combined and joint operations with aerial bombardment, close air support with napalm, and amphibious operations.” 157

Much of the French Foreign Legion spent a majority of their time in the De Lattre Line in one of the 920 blockhouses and posts securing the Tonkin Delta, which were more like prisons susceptible to surprise attacks than jumping off points to secure the countryside. ${ }^{158}$ The $1 \mathrm{er}$ BEP complained about patrolling the countryside in 1953 claiming “[t]he battalion [was] often badly informed” and had "no intelligence concerning the general situation or the particular one.”159

${ }^{154}$ Porch, 530.

155 Ibid., 546.

${ }^{156}$ Kelly, 48; Fall, 268; Jacques Dalloz, The War in Indo-China, 1945-54, trans. Josephine Bacon (Savage, MD: Barnes and Noble, 1990), 147.

${ }^{157}$ Fall, 37-38, 44; Porch, 549-550.

158 Porch, 537.

${ }^{159}$ Ibid., 539. 
Much of the pacification efforts were doomed to failure because of a lack of political or social actions to accompany military operations. ${ }^{160}$ Many above the tactical level of French leadership, military and civilian alike did not yet grasp the distinction between their traditional notions of pacification and the revolutionary war their soldiers were fighting. English legionnaire Henry Ainly was of the opinion that pacification just was not the Legion's forte:

The men of the Foreign Legion were first-class soldiers, but they had nothing whatsoever to do with a mission of pacification and political re-education...The Foreign Legion was brilliant at two things - killing and dying well, both of which the Légionnaires did frequently and with éclat. But that had little to do with protecting the quiet little yellow man who surrounded us, hated us cordially and occasionally got round to murdering us when they saw the chance. ${ }^{161}$

Vietnamese auxiliary forces were supposed to offset the manning problems in Indochina by attaching recruits to established French units. Although these "parasite” battalions added badly needed troop strength, they were of a lower caliber. The 1er BEP protested in 1953 about receiving "recruits who knew nothing of the war and who were often physically unfit." 162 After de Lattre died of cancer on 11 January 1952, subsequent commanders, Generals Raoul Salan and Henri Navarre could not turn the tide of the war. ${ }^{163}$ The French government told General Navarre in May 1953 that no substantial increase in aid was coming from France, that he must protect Laos as France's best ally in the region, and that he must achieve "positions of strength” from which negotiations could take place. ${ }^{164}$ A small tactical victory at the base aéroterrestre at Na Son provided a false hope in the French ability to withstand massive Vietminh assaults from well-supplied air-land bases. ${ }^{165}$

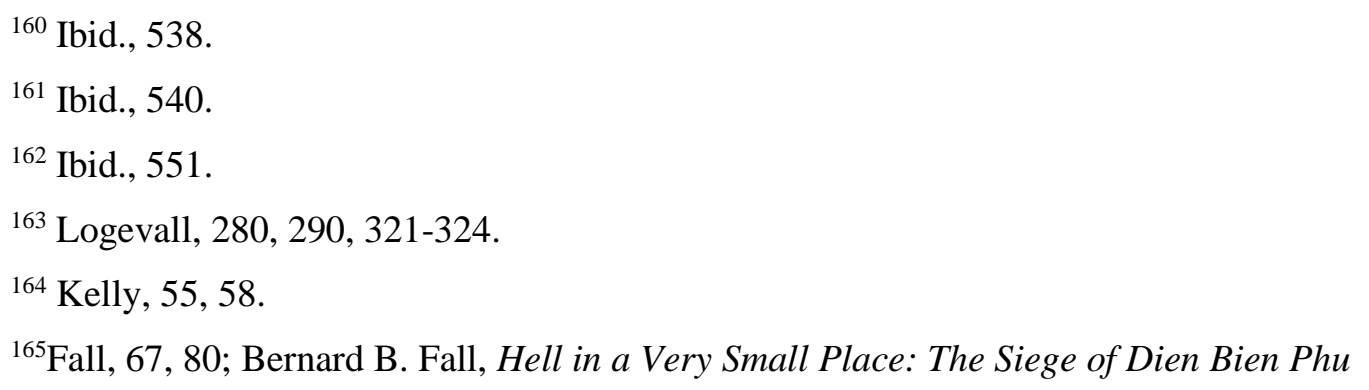


Based upon the success of Na Son and the idea that better terrain would greatly improve the effectiveness of the base aéro-terrestre concept, Navarre undertook Operation Castor, which ended with the loss at Dien Bien Phu, to accomplish the objectives desired in Paris. ${ }^{166}$ The 1er BEP, as veterans of Na San, were some of the first troops dropped into the Nam Yum river valley around Dien Bien Phu on 21 November 1953 and surrendered with honor on 7 May 1954—what was left of them. ${ }^{167}$ Unit officers of the 1er BEP loathed important visits from high-ranking officials during the operation who came to see the progress of their plans and considered them pointless interruptions that keep them from the important business at hand. ${ }^{168}$ Dien Bien Phu did not fool the veterans of the 1er BEP, unlike their important visitors who felt it was a better version of Na Son. ${ }^{169}$ The Legionnaires knew there were too many differing variables that did not favor the French defenders in this case.

A seemingly impossible mission given to them by the French government frustrated legionnaires of the 1er BEP. Jean Lartéguy captured the essence of many Legionnaire feelings during the closing actions in Indochina in The Centurions when Captain Glatingny uttered "[a] boy of twenty, twenty years of hope and enthusiasm dead. That's a hell of a capital to throw away, and can’t be easily recovered. I wonder what they think about it in Paris.” ${ }^{170}$ The defeat at Dien Bien Phu was the precipitating event for peace negotiations, which ended the war as public awareness and lack of support for the cost of continuing the conflict became increasingly distasteful at home. The First Indochinese War was a political and military defeat for the French.

(Cambridge, MA: Da Capo Press, 2002), 24.

${ }^{166}$ Fall, Hell in a Very Small Place: The Siege of Dien Bien Phu, 24, 31-32.

${ }^{167}$ Ibid., 15-16; Martin Windrow, The Last Valley: Dien Bien Phu and the French Defeat in Indochina (Cambridge, MA: Da Capo Press, 2006), 244-245.

168 Windrow, 330.

169 Ibid., 348.

${ }^{170}$ Jean Lartéguy, The Centurions, trans. Xan Fielding, 1st ed. (New York, NY: Dutton, 1962), 26. 
Table 3.1 Assessment of strategic culture variable (Indochina)

\begin{tabular}{|c|c|c|}
\hline Variable & Indicator & Assessment \\
\hline \multirow{3}{*}{$\begin{array}{l}\text { Strategic } \\
\text { Culture }\end{array}$} & $\begin{array}{l}\text { Independence (ability of France to think and act for } \\
\text { herself) } \\
\text { 1) Strength of national feeling } \\
\text { 2) Reaffirmation by those who are "a certain kind } \\
\text { of France" } \\
\text { 3) Decision-making autonomy }\end{array}$ & $\begin{array}{l}\text { Willing to act on behalf of } \\
\text { French interest against } \\
\text { global opinion }\end{array}$ \\
\hline & $\begin{array}{l}\text { Universalism (defend and export Universal Human } \\
\text { Rights) } \\
\text { 1) "Civic assimilation" (human rights, language, } \\
\text { civic values, and cultural identity) } \\
\text { 2) "Civilizing mission" (culture imperialism) }\end{array}$ & $\begin{array}{l}\text { Committed to Universalist } \\
\text { principles, but } \\
\text { independence was } \\
\text { unacceptable }\end{array}$ \\
\hline & $\begin{array}{l}\text { Great Power Status (global stature) } \\
\text { 1) Level of international ambition } \\
\text { 2) Foreign policy orientation } \\
\text { 3) Willingness to use military force }\end{array}$ & $\begin{array}{l}\text { Perceived obligation to } \\
\text { regain global influence by } \\
\text { maintaining the colonial } \\
\text { empire at all costs. } \\
\text { Diplomacy by force. }\end{array}$ \\
\hline
\end{tabular}

Source: Author assessment of strategic culture in Indochina.

Table 3.2 Assessment of military organizational culture variable (Indochina)

\begin{tabular}{|c|c|c|}
\hline Variable & Indicator & Assessment \\
\hline \multirow{3}{*}{$\begin{array}{l}\text { Military } \\
\text { Organizational } \\
\text { Culture }\end{array}$} & $\begin{array}{l}\text { Relationship to the State (positive or negative) } \\
\text { 1) Feeling of acceptance and value } \\
\text { 2) Centralized or decentralized control } \\
\text { 3) Level of support (monetary, logistical, } \\
\text { manpower) }\end{array}$ & $\begin{array}{l}\text { History of distrust since } \\
\text { 1940, decentralized } \\
\text { control to weaken military } \\
\text { power, poorly supported, } \\
\text { and politically } \\
\text { undermined }\end{array}$ \\
\hline & $\begin{array}{l}\text { Military valued skills (method and mode of } \\
\text { combat) } \\
\text { 1) Strategy of annihilation or attrition } \\
\text { 2) Conventional or unconventional warfare } \\
\text { 3) Joint and combined operations }\end{array}$ & $\begin{array}{l}\text { French need to show } \\
\text { proficiency in WWII era } \\
\text { tactics and operations due } \\
\text { to the } 1940 \text { performance }\end{array}$ \\
\hline & $\begin{array}{l}\text { Evaluation of the enemy (superior, peer, or } \\
\text { inferior adversary) } \\
\text { 1) Motivation for fighting } \\
\text { 2) Ability to fight } \\
\text { 3) Capabilities for fighting }\end{array}$ & $\begin{array}{l}\text { Did not understand why } \\
\text { the enemy was fighting } \\
\text { and underestimated their } \\
\text { abilities and capabilities }\end{array}$ \\
\hline
\end{tabular}

Source: Author assessment of military organizational culture in Indochina. 
The Suez Crisis (1956)

The post-Second World War decolonization movement and quest for independence by third world countries was also an issue for the French in North Africa. One of the biggest proponents of national self-determination in the region was the President of Egypt, Gamal Abdel Nasser, whose country was in an ideal position to influence North Africa. The French learned in Indochina that rebellions needed external support to succeed and they believed help (training and equipment) and encouragement ("Voice of the Arabs” radio program) from Nasser contributed significantly to their struggles in Algeria. ${ }^{171}$

Nasser’s nationalization and seizure of the Suez Canal from the French-based consortium, the Suez Canal Company, on 26 July1956 provided France an opportunity to address its Algerian concerns. ${ }^{172}$ The Suez Crisis was a chance for France to advance their desire to act more independently from the United States in pursuit of their own peacemaking policy in the Middle East. ${ }^{173}$ The Munich Syndrome (fear of repeating Nazi appeasement) greatly affected French leaders and this moral justification for action against Egypt appealed to their Second World War experience. ${ }^{174}$ A successful military operation in the Suez could possibly redeem French performances in 1940 and in Indochina. French Prime Minister, Guy Mollet believed his

${ }^{171}$ André Martin, "The Military and Political Contradictions of the Suez Affair: A French Perspective," in The Suez-Sinai Crisis, 1956: Retrospective and Reappraisal, ed. S. Ilan Troen and Moshe Shemesh (New York, NY: Columbia University Press, 1990), 54-55.

${ }^{172}$ Chaim Herzog, "The Suez-Sinai Campaign: Background," in Suez 1956: The Crisis and Its Consequences, ed. William Roger Louis and Roger Owen (Oxford, UK: Clarendon Press, 1989), 5.

173 Jean-Paul Cointet, "Guy Mollet, the French Government and the SFIO," in The SuezSinai Crisis, 1956: Retrospective and Reappraisal, ed. S. Ilan Troen and Moshe Shemesh (New York, NY: Columbia University Press, 1990), 129.

${ }^{174}$ Ibid., 131; Maurice Vaisse, "France and the Suez Crisis," in Suez 1956: The Crisis and Its Consequences, ed. William Roger Louis and Roger Owen (Oxford, UK: Clarendon Press, 1989), 134. 
analysis of the situation was correct and there was

the need to stand up to Nasser's action, and to refuse to give in to the violation of agreements; the conviction that Israel's existence was subject to a deadly threat; the fear that the balance of power in the Middle East might be disturbed in a way fatal to the West; and the existence of links between Nasserism and the Algerian situation. ${ }^{175}$

Mollet believed taking military action against a Soviet satellite nation would keep the United States from condemning French action while displaying the ability of European countries to act on their own. ${ }^{176}$ French Foreign Minister, Christian Pineau was very clear about the French North African preoccupation with respect to the Suez affair and “[i]f Egypt’s action remained without a response, it would be useless to pursue the struggle in Algeria" and that "France consider[ed] it more important to defeat Colonel Nasser's enterprise than to win ten battles in Algeria.” ${ }^{177}$ Pineau also feared the loss of Algeria because "the loss of North Africa would then be followed by that of Black Africa and the entire territory would rapidly escape European control and influence.»178 In the Suez, the French government and military saw the prospect of turning the tide of the Algerian War in French favor, thereby keeping Algeria from the same fate as Indochina. ${ }^{179}$ The French Foreign Legion welcomed the Suez expedition. ${ }^{180}$ The first reason being the nature of the operation and need for power projection would mean a heavy reliance on their elite paratroopers of the 1er BEP (a full regiment as of 1 August 1955). ${ }^{181}$ Secondly, the removal of

\footnotetext{
${ }^{175}$ Cointet 135.

176 Ibid.

177 Vaisse 137.

178 Ibid.
}

${ }^{179}$ Adam Watson, "The Aftermath of Suez: Consequences for French Decolonization," in Suez 1956: The Crisis and Its Consequences, ed. William Roger Louis and Roger Owen (Oxford, UK: Clarendon Press, 1989), 341.

${ }^{180}$ Porch, 578.

${ }^{181}$ Derek Varble, The Suez Crisis, 1956, Essential Histories (New York, NY: Osprey Publishing, 2003), 17; Legion. 
Nasser with evidence secured of his involvement in Algeria would decapitate the Front de Libération Nationale (FLN) support effort and restore army morale. ${ }^{182}$ The French military was so convinced the key to Algeria lay in Egypt they committed 34,000 men, 2,900 pilots, 150 fighter and bomber aircraft, an air transport group, 10,000 vehicles, 25,000 metric tons of equipment, and their Mediterranean fleet to conduct the invasion. ${ }^{183}$ The 1er REP jumped into action over Port Said on 5 November 1956 to eliminate Egyptian resistance, secure the city waterworks, and prepare the area for Anglo-French amphibious landings. ${ }^{184}$ The 1er REP "scattered the Egyptians like rabbits and displayed a sort of raw efficiency [honed in Indochina] that left their British counterparts blinking with disbelief." ${ }^{185}$ In the midst of the 1er REP executing their mission with great success the British and French governments agreed to a United Nations ceasefire on November 6, 1956 due to external pressure. ${ }^{186}$

The 1er REP felt betrayed by their Anglo-Saxon allies, the West, and the Fourth Republic. Many Legionnaires like Kemencei, felt “[they] no longer had any faith... [Their] professionalism remained intact. But [they] no longer wanted to fight for causes lost in advance...” ${ }^{187}$ General Jacques Massu, commander of the French paratroops in the Suez, said his men obeyed the ceasefire with "with rage in the heart... when Cairo seem[ed] to us just around the corner, with no serious obstacle to prevent our advance.” ${ }^{188}$ To make the betrayal worse the Legionnaires of the 1er REP and Massu returned to Algeria to find out the FLN capitalized on the

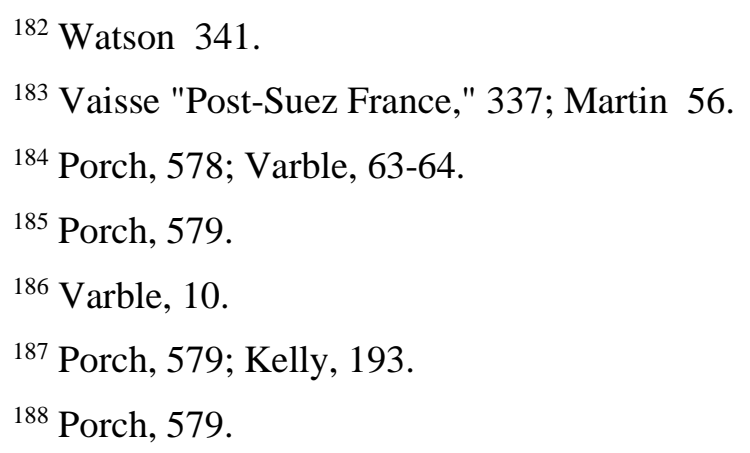


outcome of the Suez Crisis and transformed it into

a triumphal victory. Not only do its faithful take heart, but those who had given over to panic want to reaffirm their loyalty... Our hearts are heavy. The deception runs through all of my beautiful division so ready to carry out a task worthy of it! We chew over without end this senseless story which has deprived us not only of a glorious victory, to which a soldier cannot remain indifferent, but also the beginning of a solution to the Algerian affair, which we are now confronting once again. ${ }^{189}$

The French military achieved a military victory over Egyptian forces, but suffered another political defeat that forced the withdrawal of French forces from the Suez, which ended the crisis.

Table 3.3 Assessment of strategic culture variable (Suez)

\begin{tabular}{|l|l|l|}
\hline Variable & \multicolumn{2}{|l}{ Indicator } \\
\hline \multirow{5}{*}{$\begin{array}{l}\text { Independence (ability of France to think and act for } \\
\text { herself) }\end{array}$} & $\begin{array}{l}\text { 1) Strength of national feeling } \\
\text { 2) Reaffirmation by those who are "a certain kind } \\
\text { of France" } \\
\text { 3) Decision-making autonomy }\end{array}$ & $\begin{array}{l}\text { No change-Willing } \\
\text { Egypt despite US } \\
\text { and Russian } \\
\text { objections }\end{array}$ \\
\cline { 2 - 3 } & $\begin{array}{l}\text { Universalism (defend and export Universal Human } \\
\text { Rights) } \\
\text { 1) "Civic assimilation" (human rights, language, } \\
\text { civic values, and cultural identity) } \\
\text { 2) "Civilizing mission" (culture imperialism) }\end{array}$ & $\begin{array}{l}\text { No change-Only } \\
\text { for French subjects } \\
\text { and unconcerned } \\
\text { about Egyptian rights }\end{array}$ \\
\cline { 2 - 3 } & $\begin{array}{l}\text { Great Power Status (global stature) } \\
\text { 1) Level of international ambition } \\
\text { 2) Foreign policy orientation } \\
\text { 3) Willingness to use military force }\end{array}$ & $\begin{array}{l}\text { No change-Belief } \\
\text { in flexing military } \\
\text { power will support } \\
\text { global status }\end{array}$ \\
\hline
\end{tabular}

Source: Author assessment of strategic culture in the Suez.

${ }^{189}$ Ibid. 
Table 3.4 Assessment of military organizational culture variable (Suez)

\begin{tabular}{|l|l|l|}
\hline \multicolumn{1}{|l|}{ Variable } & $\begin{array}{l}\text { Andicator } \\
\text { Relationship to the State (positive or negative) } \\
\text { 1) Feeling of acceptance and value } \\
\text { 2) Centralized or decentralized control } \\
\text { 3) Level of support (monetary, logistical, } \\
\text { manpower) }\end{array}$ & $\begin{array}{l}\text { More negative } \\
\text { because of another } \\
\text { case of perceived } \\
\text { political } \\
\text { undermining by the } \\
\text { government }\end{array}$ \\
\cline { 2 - 3 } $\begin{array}{l}\text { Military } \\
\text { Culture }\end{array}$ & $\begin{array}{l}\text { Military valued skills (method and mode of combat) } \\
\text { 1) Strategy of annihilation or attrition } \\
\text { 2) Conventional or unconventional warfare } \\
\text { 3) Joint and combined operations }\end{array}$ & $\begin{array}{l}\text { No change-WWII } \\
\text { era }\end{array}$ \\
\cline { 2 - 3 } & $\begin{array}{l}\text { Evaluation of the enemy (superior, peer, or inferior } \\
\text { adversary) } \\
\text { 1) Motivation for fighting } \\
\text { 2) Ability to fight } \\
\text { 3) Capabilities for fighting }\end{array}$ & $\begin{array}{l}\text { Inferior-Similar } \\
\text { conventional military } \\
\text { force, but no match } \\
\text { for the hardened } \\
\text { veterans of the } \\
\text { French Army }\end{array}$ \\
\hline
\end{tabular}

Source: Author assessment of military organizational culture in the Suez.

The Algerian War (1956-1962)

Just a few months after the French defeat at Dien Bien Phu, the FLN initiated armed resistance to French colonial rule in pursuit of Algerian independence. By 1956, the Algerian War was the principal French political issue and unlike Indochina, was not a remote colony thousands of miles away, but contained three departments of metropolitan France represented in parliament. ${ }^{190}$ The French saw the rebellion as an internal issue of pacification and integration, while the Algerian nationalists sought the goal of "a sovereign, democratic, and social Algerian state within the framework of Islamic principles.”" 191 Premier Edgar Faure in November 1954,

\footnotetext{
${ }^{190}$ Vaisse "France and the Suez Crisis," 137; Watson 341; Keiger, 210.

${ }^{191}$ Carmoy, 155.
} 
addressed the situation in Algeria by saying,

One does not compromise when it is a matter of defending the internal peace of a nation, the unity, the integrity of the Republic. The departments of Algeria constitute a part of the French Republic. They have been irrevocably French for a long time...Algeria is France. $^{192}$

French sentiments were at dire odds with Algerian nationalist goals. Since 1830, the French people believed they “discovered [in Algeria] a curious wonderland of its own dimensions that seemed strangely suited to be called ‘France.”’ ${ }^{193}$ Jacques Soustelle, Governor-General of Algeria, in January 1955 proclaimed, “France would no more leave Algeria than she would leave Provence or Brittany.” 194 These feelings expressed by the French government aligned nicely with the attitudes of the military. Algeria was of very special importance to the Foreign Legion who were mystically bonded to the land through Sidi-bel-Abbès, "the epicenter of its geographical and spiritual existence,” which "sat [in the desert] like some miniature Vatican.” ${ }^{195}$ Many soldiers felt "to bleed on such magnetic soil was somehow to possess it by right." ${ }^{196}$ Some voices in France argued, “Algeria was the measure of France’s noble experiment of economic generosity and cultural assimilation...” ${ }^{197}$ The French Army reeling from Indochina and the Suez considered the conflict in Algeria to be "the war that, even against the will of God or man, could not be lost.”198

To oppose French rule, Algerian nationalists championed French ideas of freedom, democracy, state-supported schools, equality, and resistance to oppression. ${ }^{199}$ Algerians were

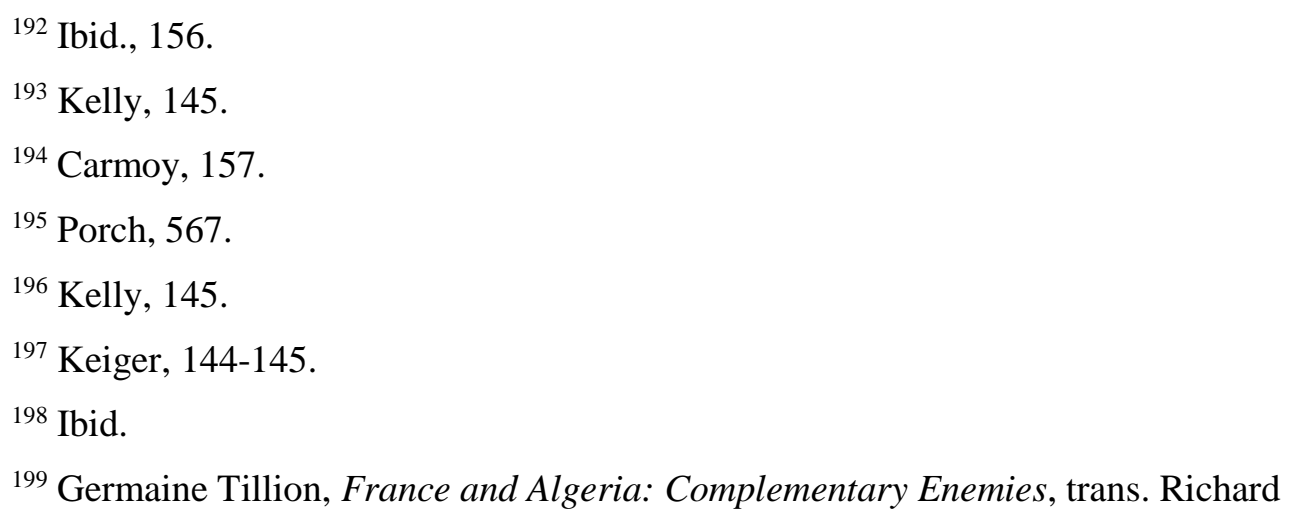


attempting to imitate French civil and military institutions and by trying to destroy them, France was really destroying an image of itself. ${ }^{200}$ French leaders made an irreparable mistake in not understanding the unalterable character of the Algerian nationalist movement. ${ }^{201}$ An Algerian official exasperatedly uttered,

You brought us your civilization...I honor France's record above all for that...You showed us the way, you gave us the taste for liberty, and now when we say that we wish to be free, to be men-no more and no less-you deny us the right to take over your own formulas. You are Frenchman, and yet you are surprised that some of us should seek independence. $^{202}$

M. Maurice Violette, a former Governor-General of Algeria cautioned French politicians and others of the impending danger of leaving Muslim elites shaped by French culture without a sense of belonging because, "they are seeking a country and they expect you [the leaders of metropolitan France] to make them French. If you do not make France their country quickly, then they will make another country their own.”203 To make Algerians French required social, political, and economic equality according to Alexis de Tocqueville as early as 1837 because, "[i]t is not enough for the French to put themselves alongside the Arabs if they do not succeed in establishing a lasting bond with them, and at length in forming from the two races a single people.”204 The French government did not recognize that their successes in civic assimilation and their civilizing mission naturally lead to a desire for independence. Domination of an empire and cultivating French Universalist principles did not support one another as, "the army has made

Howard, 1st American ed. (New York, NY: Alfred A. Knopf, 1961), 9.

${ }^{200}$ Ibid.

201 Ibid., 11.

202 Dorothy Maud Pickles, Algeria and France: From Colonialism to Cooperation (New York, NY: Frederick A. Praeger, 1963), 11.

203 Ibid., 21.

${ }^{204}$ John E. Talbott, The War Without a Name: France in Algeria, 1954-1962, 1st ed. (New York, NY: Alfred A. Knopf, 1980), 13. 
French patriots of Arabs and Berbers... while the schools have only too often produced intellectuals who revolted against French colonialism in the name of Republican principles.”205 The post-Second World War reality was that France was "incapable of assimilating rapidly 40 million people belonging to economically retarded countries [which was] sentimentalism, and this most generous of myths [had] been destroyed by the facts of the twentieth century.”206

As early as 1954, Pierre Mendès-France set France and Algeria on a collision course that would not have a peaceful and neat solution when he declared, 'L'Algérie, c'est la France. And who among you ... would hesitate to employ every means to preserve France?”207 In addition, he insisted the military repress the rebellion before making any concessions to the terrorists in Algeria. ${ }^{208}$ The Left wing, wary of the projected French path, elected Guy Mollet as Premier on 1 February 1956, using the slogan, “An idiotic war, with no way out.” ${ }^{209}$ Mollet promised he would, "strengthen the indissoluble union between Algeria and metropolitan France, to respect the 'Algerian personality,' [and] to achieve total political equality for all the inhabitants of Algeria,” with free elections as soon as possible. ${ }^{210}$ Mollet's harsh reception in Algeria shortly after coming to power quickly squashed hopes of any liberal policy solution as the situation became irreconcilable. ${ }^{211}$ A French lawyer adeptly announced, "We have aroused Algeria, now we will arouse metropolitan France.”212 Neither the French parliament nor the people were very

${ }^{205}$ Herbert Lüthy, France against Herself: A Perceptive Study of France's Past, Her Politics, and Her Unending Crises (New York, NY: Praeger, 1955), 17.

\footnotetext{
206 Pickles, 53.

${ }^{207}$ Porch, 568.

208 Ibid.

${ }^{209}$ Carmoy, 157.

${ }^{210}$ Ibid.

${ }^{211}$ Ibid., 158.

${ }^{212}$ Ibid.
} 
happy with the policy alternatives of integration, independence, or partition, so the only course was to continue assimilation. ${ }^{213}$ A very ugly war began in earnest and a few short months later in August 1956 there were approximately 400,000 French soldiers fighting in Algeria. ${ }^{214}$

The beginning of the Algerian War caught many French forces in transit from Indochina and quite a few straight from Viet Minh prisoner of war (POW) camps. The French military deployed to Algeria ill-equipped with First World War era surplus, poor rations, and inadequate accommodations and for Kemencei, "it was only with difficulty that [he] could overcome [his] anger." ${ }^{215}$ Additionally, the French government deducted the food allowance from back pay for Legionnaires like Kemencei while they were POWs because the Viet Minh fed them in captivity. ${ }^{216}$ The Algerian War began with increased mistrust between the French military and government because of these events in conjunction with Indochina, Morocco and Tunisia gaining independence, but the military believed deep down that any compromise on Algeria would be “quite impossible.”217 According to General Massu, even despite “[t]he inconsistency of the IVth Republic, upon whom [they] had a tendency to blame Dien Bien Phu, led [them] to believe that the army was [still] the ultimate rampart of the country’s honor.”218

North Africa was the traditional sphere of influence for the French military and after Dien Bien Phu many soldiers felt, "better death than dishonor” before accepting another humiliation so close to metropolitan France due to the legacy of Indochina. ${ }^{219}$ With prophetic accuracy, Marshal

\footnotetext{
${ }^{213}$ Ibid., 161.

${ }^{214}$ Ibid., 159.

${ }^{215}$ Porch, 573-574.

${ }^{216}$ Ibid., 566.

${ }^{217}$ Ibid., 566-567.

${ }^{218}$ Ibid., 566.

${ }^{219}$ Keiger, 65; Kelly, 147.
} 
Bugeaud over one hundred years previously, foreshadowed events when he saw "no prospect of a government strong enough to get out of Algeria, even if such a step were indicated by the trend of events there...Since withdrawal is impossible the only remaining alternative is total domination.”220 Based upon the French army’s studies of the conflicts in Indochina, Iran, and Greece they felt the only way of combating revolutionaries was by using the enemy's own methods. ${ }^{221}$ The resident Minister of Algeria, Robert Lacoste in August 1956, stated, "We wage a very special combat. It is modern revolutionary war, above all psychological, with the adherence of the population at stake.”222

General Massu and his elite $10^{\text {th }}$ Parachute Division believed compared to Indochina, that Algeria would be an easier situation to handle and "the effort required of [them] so close to the metropole, in an incomparably easier terrain and climate, seemed to [them] easy enough.” ${ }^{223}$ The school of thought based upon the Indochinese experience believed the Algerian War required la guerre révolutionnaire with doctrine and unit organizations adapted to meet those demands. ${ }^{224}$ This adaptation though came at the expense of force modernization in accordance with North Atlantic Treaty Organization plans. ${ }^{225}$ The French army’s theme was that of pacification based upon reforms and targeted information operations to keep up the population's morale. ${ }^{226}$ The ideas of "war in the crowd" and "war for the crowd" were very popular in professional military

${ }^{220}$ Kelly, 166.

${ }^{221}$ Michael Kettle, De Gaulle and Algeria, 1940-1960: From Mers El-Kébir to the Algiers Barricades (London, UK: Quartet Books Limited, 1993), 160.

${ }^{222}$ Kelly, 169.

${ }^{223}$ Porch, 570.

${ }^{224}$ Kelly, 182-183.

225 Ibid.

${ }^{226}$ Kettle, 160. 
journals and the military quickly developed techniques for waging such a war. ${ }^{227}$ The primary techniques to conduct this type of warfare revolved around the combination of bouclage and quadrillage (sealing off an enemy area in a grid coverage pattern with an elite mobile unit driving the enemy forces into blocking positions), the Morice Line, and resettlement with reeducation. ${ }^{228}$

Resettlement involved regroupement (relocating) of approximately two million Muslims into 1840 villages with the purpose of denying the enemy access to the population and providing pro-French reeducation. ${ }^{229}$ All these techniques proved quite successful in both urban (The Battle of Algiers, 1957) and rural areas (Challe Offensive, 1959), however FLN defeats on the battlefields did not equate to political victories for the French. The use of torture helped secure tactical victories, but reports of this type of activity caused the French to lose the war in the eyes of public opinion. Reports of torture and books like, Lieutenant in Algeria by Jean-Jacques Servan-Schreiber undermined French military efforts domestically and internationally and drained French political will to continue prosecuting the war. ${ }^{230}$ Although the FLN committed atrocities on their own people, the West and international community heard more about French torture. $^{231}$

Simon Murray, a former Legion paratrooper, noted in his diary in 1960 that

With all the good results... [there] was a steady build-up of hatred for the French-a hatred that comes from living in fear and terror...The French became the foreign intruder and the concept of nationalism was born in the Arabs... We mercenaries fight for a lost cause - a cause that will be buried in the French political arena, not here. I wonder how

${ }^{227}$ Kelly, 183.

${ }^{228}$ Porch, 574; Kelly, 188.; The Morice Line completed in 1957 blocked off the borders with Morocco and Tunisia. The line consisted of fixed fortifications with electrified wire, high walls interspersed with mine fields, lights for nighttime, and patrolled continuously.

${ }^{229}$ Porch, 575; Kelly, 188.

${ }^{230}$ Keiger, 65.

${ }^{231}$ Kettle, ix. 
many more crosses must be struck before the end comes - the end for the French, when a new nation will be born, conceived entirely through French misunderstanding. ${ }^{232}$

Not all military members felt so forlorn and the French army was integral in bringing Charles de Gaulle back to power in 1958. The French military was very confident that General De Gaulle would see the Algerian War through to the victory, which they felt, was within their grasp. Just a little over a year later, however, de Gaulle came to the realization that French Algeria was a "lamentable stupidity" and the best France could hope for was a draw, which in the eyes of the world was a FLN victory. ${ }^{233}$

De Gaulle envisioned a “government of Algerians by Algerians” being possible within four years of a peace treaty and this struck a heavy blow to the French army who believed he was snatching victory from those who put him in power. ${ }^{234}$ The world was changing after the Second World War and de Gaulle understood achievement of French grandeur was a nuclear proposition and that the world measured power not in square kilometers of empire, but rather in megatonnage of nuclear weapons yield. ${ }^{235}$ World power required France to create a modern nuclear force in Europe that was as a "third force" to counter US and Russian hegemony, and it seemed “contrary to the present interest and new ambition of France to remain bound by obligations and burdens [in Algeria] that no longer fit its power and interest.”236

The French military did not have the same change of heart as De Gaulle. Jean Lartéguy captures this feeling of betrayal in his conversation between Raspéguy and Esclavier in The Centurions about subpoenas to appear in court for their actions in the Battle of Algiers:

\footnotetext{
232 Porch, 587.

233 Ted Morgan, My Battle of Algiers (New York, NY: Collins/Smithsonian, 2006), 267.

234 Ibid.

${ }^{235}$ Keiger, 72, 210.

${ }^{236}$ Kelly, 374, 377; Keiger, 72.
} 
And yet "they" [the French government] told us to use every means at our disposal to win...Now that they're no longer shitting themselves with fear, they send us these little bits of paper...We're doing this job because [the government] ordered us to, but it repels and disgusts us... [government officials say] It's for the sake of France...[Esclavier responds] Let Rome beware of the anger of the legions. ${ }^{237}$

The feeling of betrayal was so strong among the elite 1er REP that they actively participated in the Generals’ Putsch of 1961 to overthrow De Gaulle because of his stance on Algeria. Major Saint-Marc declared that, “fifteen years [Indochina through Algeria] of hope turned out to be fifteen years of deceit.”238 Captain Estoup participated in the putsch because he remembered his experience witnessing the fate of Vietnamese villagers who cast their lot with the French in Indochina [killed by the Viet Minh or drowned trying to swim to departing French ships]:

When one has been implicated once in such a tragedy, one swears never to be an accomplice in it again... The army had made a solemn pledge to preserve Algeria as French territory and not to abandon its population to the FLN. ${ }^{239}$

General Challe, one of the leaders of the putsch, added, "We engaged at our sides hundreds of thousands of Muslims knowing perfectly well they would pay with their lives for their confidence in France, in the word of France.” ${ }^{240}$ For many, resignation was not enough of an opposing statement to the ending of the Algerian War and revolting was the only honorable course of action. The French government defeated the putsch in three days and set to transforming the French military for its new role in the world as De Gaulle reminded officers and men that, "As soon as the state and the nation have chosen their path, military duty is marked out once and for all. Beyond its rules, there can be, there are only lost soldiers.”241 The ending of the Algerian War saw too the end of the French colonial empire. The French military learned from its experiences

\footnotetext{
${ }^{237}$ Lartéguy, 486.

238 Talbott, 214.

${ }^{239}$ Ibid., 196-198.

${ }^{240}$ Ibid., 198.

${ }^{241}$ Ibid., 215.
} 
and adapted to bring France a military victory in Algeria, however, once again French strategic culture placed the military in an unwinnable situation.

Table 3.5 Assessment of strategic culture variable (Algeria)

\begin{tabular}{|c|c|c|}
\hline Variable & Indicator & Assessment \\
\hline \multirow{3}{*}{$\begin{array}{l}\text { Strategic } \\
\text { Culture }\end{array}$} & $\begin{array}{l}\text { Independence (ability of France to think and act for } \\
\text { herself) } \\
\text { 1) Strength of national feeling } \\
\text { 2) Reaffirmation by those who are "a certain kind of } \\
\text { France" } \\
\text { 3) Decision-making autonomy }\end{array}$ & $\begin{array}{l}\text { No change-Began } \\
\text { promoting the idea of } \\
\text { a "third" or balancing } \\
\text { force to the bipolar } \\
\text { nature of the global } \\
\text { landscape }\end{array}$ \\
\hline & $\begin{array}{l}\text { Universalism (defend and export Universal Human } \\
\text { Rights) } \\
\text { 1) "Civic assimilation" (human rights, language, civic } \\
\text { values, and cultural identity) } \\
\text { 2) "Civilizing mission" (culture imperialism) }\end{array}$ & $\begin{array}{l}\text { No change-Did not } \\
\text { feel the natural } \\
\text { progression of } \\
\text { civilizing missions } \\
\text { and assimilation was } \\
\text { independence }\end{array}$ \\
\hline & $\begin{array}{l}\text { Great Power Status (global stature) } \\
\text { 1) Level of international ambition } \\
\text { 2) Foreign policy orientation } \\
\text { 3) Willingness to use military force }\end{array}$ & $\begin{array}{l}\text { No change-Shifted } \\
\text { from a colonial } \\
\text { empire to nuclear } \\
\text { capability as the } \\
\text { sources of global } \\
\text { power }\end{array}$ \\
\hline
\end{tabular}

Source: Author assessment of strategic culture in Algeria. 
Table 3.6 Assessment of military organizational culture variable (Algeria)

\begin{tabular}{|c|c|c|}
\hline Variable & Indicator & Assessment \\
\hline \multirow{3}{*}{$\begin{array}{l}\text { Military } \\
\text { Organizational } \\
\text { Culture }\end{array}$} & $\begin{array}{l}\text { Relationship to the State (positive or negative) } \\
\text { 1) Feeling of acceptance and value } \\
\text { 2) Centralized or decentralized control } \\
\text { 3) Level of support (monetary, logistical, } \\
\text { manpower) }\end{array}$ & $\begin{array}{l}\text { Completely Broken- } \\
\text { Disenfranchised with a } \\
\text { feeling politics was } \\
\text { the only recourse to } \\
\text { settle grievances lead } \\
\text { to the Putsch of } 1961\end{array}$ \\
\hline & $\begin{array}{l}\text { Military valued skills (method and mode of } \\
\text { combat) } \\
\text { 1) Strategy of annihilation or attrition } \\
\text { 2) Conventional or unconventional warfare } \\
\text { 3) Joint and combined operations }\end{array}$ & $\begin{array}{l}\text { La guerre } \\
\text { révolutionnaire-_ } \\
\text { developed a new } \\
\text { doctrine based upon } \\
\text { experiences in } \\
\text { Indochina to guide a } \\
\text { new operational } \\
\text { approach in Algeria to } \\
\text { fight revolutionary } \\
\text { war }\end{array}$ \\
\hline & $\begin{array}{l}\text { Evaluation of the enemy (superior, peer, or inferior } \\
\text { adversary) } \\
\text { 1) Motivation for fighting } \\
\text { 2) Ability to fight } \\
\text { 3) Capabilities for fighting }\end{array}$ & $\begin{array}{l}\text { Inferior-culturally } \\
\text { superior and with a } \\
\text { new doctrine and } \\
\text { operational approach } \\
\text { the French could beat } \\
\text { the enemy at their own } \\
\text { game }\end{array}$ \\
\hline
\end{tabular}

Source: Author assessment of military organizational culture in Algeria.

Table 3.7 Comparison of variables across case studies

\begin{tabular}{|c|c|c|}
\hline \multirow{2}{*}{ Case Studies } & \multicolumn{2}{|c|}{ Variables } \\
\hline & Strategic Culture & Military Organizational Culture \\
\hline Indochina & $\begin{array}{l}\text { Strategic culture was consistent } \\
\text { throughout the period under } \\
\text { investigation consisting of the First } \\
\text { Indochinese War, the Suez Crisis, and }\end{array}$ & $\begin{array}{l}\text { The French military tried to fight } \\
\text { WWII over again in Indochina with } \\
\text { very little success. Although they } \\
\text { became proficient at this conventional }\end{array}$ \\
\hline Suez & $\begin{array}{l}\text { the Algerian War. French strategic } \\
\text { culture on all three occasions } \\
\text { compelled French politicians and } \\
\text { officials to employ the military as } \\
\text { their primary means of diplomacy in }\end{array}$ & $\begin{array}{l}\text { type of warfare, it was the wrong } \\
\text { operational approach to revolutionary } \\
\text { warfare. The French military, } \\
\text { however, learned and adapted from } \\
\text { their experience to achieve success in }\end{array}$ \\
\hline Algeria & $\begin{array}{l}\text { situations that were not politically, } \\
\text { financially, or popularly able to } \\
\text { achieve victory, despite a learning and } \\
\text { adaptive military organization. }\end{array}$ & $\begin{array}{l}\text { the Algerian War. They developed a } \\
\text { new doctrine and used it to guide a } \\
\text { different operational approach from } \\
\text { Indochina. }\end{array}$ \\
\hline
\end{tabular}

Source: Author comparison of variables across all case studies. 


\section{Conclusion}

Sun Tzu advised military leaders of the importance of not only knowing oneself, but also the enemy. The greater the level of knowledge so should be the level of success. The French experiences in Indochina, the Suez, and Algeria were relevant historical case studies to evaluate Sun Tzu's axiom and determine if this idea remains pertinent today for the US Army. According to Klein, the French should be quite adept at matching culture with the appropriate strategy, doctrine, and operations based upon their extensive military experience in the post-Second World War period. The French, however, lost the First Indochinese War, the Suez Crisis, and the Algerian War and their strategy did not translate into victory. The French experience in Indochina, the Suez, and Algeria revealed that French strategic culture was persistent, unchanging, and influential, and despite this, the military was able to learn from their experiences and adapt to revolutionary warfare. The French government, wedded to their strategic culture, failed to understand the greater strategic context in which they committed their military forces. This ignorance led directly to political defeat in Indochina, the Suez, and Algeria despite everimproving French military campaigns.

French strategic culture remained highly independent, Universalist, and motivated by the desire to keep great power status at all costs. Unfortunately, the tenets of French strategic culture were often in conflict with one another and at odds with the international community. The strength of national feeling for the conflicts in Indochina, the Suez, and Algeria was quite high amongst French leaders and the population until the political and domestic cost became too high.

Despite the many changeovers in the national government, every French leader from the end of the Second World War through the Algerian War carried on de Gaulle’s ideas of French grandeur. De Gaulle and others represented “a certain kind of France” that would become a world 
power again, the champion for human rights, and represent the highest level of society. ${ }^{242}$ To implement these ideas the French believed in their need for decision-making autonomy. The French chose to reassert control in Indochina and to pacify the Algerian insurrection after the end of the Second World War even though the most influential nations of the world were pushing for national self-determination and decolonization. During the Suez Crisis, the French government chose to intervene with military force in spite of American, Russian, and global resistance to nondiplomatic methods in order to demonstrate that European nations had the ability to act on their own, and pursue their agenda in Algeria.

The French policy towards Indochina was in direct violation of the Atlantic and United Nations Charters as well as its Universalist principles of civic assimilation and civilizing missions. The Vietnamese were willing to nurture and grow their French cultural roots and continue to civilize under French influence, however as an independent nation and citizens of their own country. The French wasted their opportunity for having the primary role in the development of Vietnam and a long-term influence as the country matured. This chance was lost because of shortsightedness in the pursuit of achieving great power status against the grain of international thought. The path to great power status for the French was to reclaim their colonial empire and to prove themselves militarily due to the French debacle during the Second World War. The French did not realize that a large colonial empire and fighting wars against national sovereignty was not a path back to great power status, but moving further away from that goal.

Military organizational culture relied almost exclusively on Second World War skill sets in military operations and campaigns as the solution for the implementation of French policy until the Algerian War. Political blunders and a perceived lack of support over time eroded trust between the government and military, which resulted in the General's Putsch of 1961. The

${ }^{242}$ Colson. 
military's relationship with the French government gradually degraded overtime in Indochina and the Suez Crisis. For conflicts with such, apparent importance to the nation, the government did not supply the military sufficiently for the mission at hand because they did not have the means to provide it. On many occasions, the French government ignored military recommendations and only considered a military solution without the necessary and mutually supporting social and political changes to accomplish the mission. Eventually the problem in Indochina was just too big for the French Expeditionary Force and after the defeat of Dien Bien Phu the government sought a political settlement. During the Suez Crisis when the military was on the verge of catastrophic success, miscalculations by the French government caused a ceasefire and the culmination of the operation before achieving any decisive results. In Algeria, the cost of military success was a dramatic global aversion to French methods, which spurned international pressure for France to give Algeria its independence.

The French military greatly improved their conventional warfighting ability in Indochina. Except for the GCMAs (French commandos), the French military dedicated itself to a strategy of annihilating the enemy through decisive battles and displaying the competency they did not have in 1940. They rapidly improved and developed combined operating concepts for airborne and amphibious operations, as well as joint operations with naval vessels and aircraft for fire and close air support. Regrettably, this type of warfare did not match up well to the revolutionary war the Vietminh were waging. During the Suez Crisis, the military threat lent itself to the type of warfare the French were perfecting in Indochina and their efficiency was highly respected by their British allies. The work of dedicated military professionals to develop a new doctrine to combat revolutionary warfare in Algeria was achieving much success in North Africa, but military victories did not translate into political successes.

French officers, David Galula and Roger Trinquier, famously codified lessons learned from Indochina in their works, Counterinsurgency Warfare and Modern Warfare, respectively 
and the French military applied them with great success in Algeria. The French military showed an ability to learn and adapt from its experiences from the Second World War and from the First Indochinese War, however French strategic culture keep putting the military in situations that were unwinnable. The French military could not win regardless of how it performed against its enemies.

The US Army can learn from these experiences by better understanding how the American culture interprets the world and how it affects other actors within the global system. This awareness of self and others should lead to the development of realistic military options for senior civilian leaders, appropriate military operations, and may include doing things that are not necessarily a part of the American culture if that is what the situation and strategic context require. If the United States and its army do not pay heed to the lessons of the French experience after the Second World War, they will doom themselves to losing global status as more and more military operations fall short of accomplishing strategic political objectives based upon a lack of understanding. The United States with respect to strategic culture has an example which "points the way for the future” in the French experience in Indochina, the Suez, and Algeria from 19451962, that “is a signpost which reads, 'Success in Opposite Direction.”,243

${ }^{243}$ Fall, Street Without Joy, 13. 


\section{Bibliography}

Alasuutari, Pertti. Researching Culture: Qualitative Method and Cultural Studies. Thousand Oaks, CA: Sage Publications, 1995.

Beisecker, Dave, "Mill's Methods." University of Nevada Las Vegas. Accessed January 29, 2015. https://faculty.unlv.edu/beisecker/Courses/Phi-102/Mills_Methods.htm.

Biehl, Heiko, Bastian Giegerich and Alexandra Jonas. "Introduction." In Strategic Cultures in Europe: Security and Defence Policies across the Continent, edited by Heiko; Giegerich Biehl, Bastian; Jonas, Alexandra. Potsdam, DE: Springer VS, 2013.

Carmoy, Guy de. The Foreign Policies of France, 1944-1968. Translated by Elaine P. Halperin. Chicago, IL: University of Chicago Press, 1970.

Clausewitz, Carl von. On War. Translated by Michael Howard and Peter Paret. Princeton: Princeton University Press, 1984.

Cointet, Jean-Paul. "Guy Mollet, the French Government and the SFIO." In The Suez-Sinai Crisis, 1956: Retrospective and Reappraisal, edited by S. Ilan Troen and Moshe Shemesh, xiv, 395 p. New York, NY: Columbia University Press, 1990.

Colson, Bruno. "La Culture Strategique Française." Stratégique, no. 53 (1992). Accessed October 10, 2014. http://www.institut-strategie.fr/strat_053_Colson.html.

Dai, Bao. "Letter from Emporer Bao Dai to General Charles De Gaulle, August 18, 1945." In Viet-Nam Crisis: A Documentary History, edited by Allan W. Cameron, I, 48-49. Ithaca, NY: Cornell University Press, 1971.

Dalloz, Jacques. The War in Indo-China, 1945-54. Translated by Josephine Bacon. Savage, MD: Barnes and Noble, 1990.

Devillers, Philippe and Jean Lacouture. End of a War: Indochina, 1954. New York, NY: Frederick A. Praeger, 1969.

Fall, Bernard B. Street Without Joy. Mechanicsburg, PA: Stackpole Books, 1994.

Fall, Bernard B. Hell in a Very Small Place: The Siege of Dien Bien Phu. Cambridge, MA: Da Capo Press, 2002.

Farrell, Theo. "Culture and Military Power." Review of International Studies 24, no. 03 (1998): 407-416.

Gray, Colin S. "Out of the Wilderness: Prime Time for Strategic Culture." Comparative Strategy 26, no. 1 (2007).

Haglund, David G. "What Good Is Strategic Culture?: A Modest Defence of an Immodest Concept." International Journal 59, no. 3 (2004): 479-502.

Herzog, Chaim. "The Suez-Sinai Campaign: Background." In Suez 1956: The Crisis and Its 
Consequences, edited by William Roger Louis and Roger Owen, xvii, 428 p. Oxford, UK: Clarendon Press, 1989.

Howlett, Darryl. The Future of Strategic Culture Comparative Strategic Cultures Curriculum Project. McLean, VA: SAIC, 2006.

Irving, R. E. M. The First Indochina War: French and American Policy, 1945-54. London, UK: Croom Helm, 1975.

Johnston, Alastair Iain. "Thinking About Strategic Culture." International Security 19, no. 4 (1995): 32-64.

Keiger, John F. V. France and the World since 1870. London, UK: Arnold, 2001.

Kelly, George Armstrong. Lost Soldiers: The French Army and Empire in Crisis, 1947-1962. Cambridge, MA: MIT Press, 1965.

Kettle, Michael. De Gaulle and Algeria, 1940-1960: From Mers El-Kébir to the Algiers Barricades. London, UK: Quartet Books Limited, 1993.

Kier, Elizabeth. "Culture and Military Doctrine: France between the Wars." International Security 19, no. 4 (1995): 65-93.

Komrij, Frank, "Strategic Culture and Divergent Security Policies of European States." EInternational Relations Students. Accessed October 10, 2014. http://www.eir.info/2012/06/17/strategic-culture-and-divergent-policies-of-european-states/.

Lantis, Jeffrey S. "Strategic Culture and National Security Policy." International Studies Review 4, no. 3 (2002): 87-113.

Lartéguy, Jean. The Centurions. Translated by Xan Fielding. 1st ed. New York, NY: Dutton, 1962.

Legion, French Foreign, "Foreign Legion Info." Accessed March 12, 2015. http://foreignlegion.info/units/1st-foreign-parachute-regiment/.

Lock, Edward. "Refining Strategic Culture: Return of the Second Generation." Review of International Studies 36, no. 3 (2010): 685-708.

Logevall, Fredrik. Embers of War: The Fall of an Empire and the Making of America's Vietnam. New York, NY: Random House, 2012.

Lüthy, Herbert. France against Herself: A Perceptive Study of France's Past, Her Politics, and Her Unending Crises. New York, NY: Praeger, 1955.

Martin, André. "The Military and Political Contradictions of the Suez Affair: A French Perspective." In The Suez-Sinai Crisis, 1956: Retrospective and Reappraisal, edited by S. Ilan Troen and Moshe Shemesh, xiv, 395 p. New York, NY: Columbia University Press, 1990. 
Mill, John Stuart. A System of Logic, Ratiocinative and Inductive, Being a Connected View of the Principles of Evidence and the Methods of Scientific Investigation. London, UK:

Harrison and Co., 1843.

Morgan, Ted. My Battle of Algiers. New York, NY: Collins/Smithsonian, 2006.

Pathak, Vibha, Bijayini Jena and Sanjay Kalra. "Qualitative Research." Perspectives in Clinical Research 4, no. 3 (2013): 192.

Pickles, Dorothy Maud. Algeria and France: From Colonialism to Cooperation. New York, NY: Frederick A. Praeger, 1963.

Porch, Douglas. The French Foreign Legion: A Complete History of the Lengendary Fighting Force. 1st ed. New York, NY: HarperCollins Publishers, 1991.

Sainteny, Jean, Ho Chi Minh and Vo Hong Khanh. "Franco-Vietnamese Preliminary Convention and Annex, March 6, 1946." In Viet-Nam Crisis: A Documentary History, edited by Allan W. Cameron, I, 77-79. Ithaca, NY: Cornell University Press, 1971.

Shy, John and Thomas W. Collier. "Revolutionary War." In Makers of Modern Strategy from Machiavelli to the Nuclear Age, edited by Peter Paret, Gordon A. Craig and Felix Gilbert, 815-862. Princeton, NJ: Princeton University Press, 1986.

Skemperis, Georgios. "Strategic Culture in Post-War Europe." International Relations Program, (2003).

Snyder, Jack L. The Soviet Strategic Culture: Implications for Limited Nuclear Operations. Santa Monica, CA: Rand, 1977.

Sondhaus, Lawrence. Strategic Culture and Ways of War. New York, NY: Routledge, 2006.

Stone, Elizabeth. Comparative Strategic Cultures Literature Review (Part 1) Comparative Strategic Cultures Curriculum Project. McLean, VA: SAIC, 2006.

Talbott, John E. The War Without a Name: France in Algeria, 1954-1962. 1st ed. New York, NY: Alfred A. Knopf, 1980.

Tillion, Germaine. France and Algeria: Complementary Enemies. Translated by Richard Howard. 1st American ed. New York, NY: Alfred A. Knopf, 1961.

Tzu, Sun. The Art of War. Translated by Ralph D. Sawyer. New York, NY: Basic Books, 1994.

Uz Zaman, Rashed. "Strategic Culture: A “Cultural” Understanding of War." Comparative Strategy 28, no. 1 (2009): 68-88.

Vaisse, Maurice. "France and the Suez Crisis." In Suez 1956: The Crisis and Its Consequences, edited by William Roger Louis and Roger Owen, xvii, 428 p. Oxford, UK: Clarendon Press, 1989.

Vaisse, Maurice. "Post-Suez France." In Suez 1956: The Crisis and Its Consequences, edited by 
William Roger Louis and Roger Owen, xvii, 428 p. Oxford, UK: Clarendon Press, 1989.

Van Evera, Stephen. Guide to Methods for Students of Political Science. Ithaca, NY: Cornell University Press, 1997.

Varble, Derek. The Suez Crisis, 1956 Essential Histories. New York, NY: Osprey Publishing, 2003.

Watson, Adam. "The Aftermath of Suez: Consequences for French Decolonization." In Suez 1956: The Crisis and Its Consequences, edited by William Roger Louis and Roger Owen, xvii, 428 p. Oxford, UK: Clarendon Press, 1989.

Windrow, Martin. The Last Valley: Dien Bien Phu and the French Defeat in Indochina. Cambridge, MA: Da Capo Press, 2006. 